\title{
Review \\ Outcomes of Pulsed Electric Fields and Nonthermal Plasma Treatments on Seed Germination and Protein Functions
}

\author{
Pankaj Attri 1,2,*(D), Takamasa Okumura ${ }^{3}$, Kazunori Koga ${ }^{3,4}\left(\mathbb{D}\right.$, Masaharu Shiratani ${ }^{1,3}$ (D), Douyan Wang ${ }^{5}$ (D), \\ Katsuyuki Takahashi ${ }^{6,7}$ (D) and Koichi Takaki ${ }^{6,7}$ (D)
}

check for updates

Citation: Attri, P.; Okumura, T.; Koga,

K.; Shiratani, M.; Wang, D.;

Takahashi, K.; Takaki, K. Outcomes of Pulsed Electric Fields and

Nonthermal Plasma Treatments on

Seed Germination and Protein

Functions. Agronomy 2022, 12, 482.

https://doi.org/10.3390/

agronomy12020482

Academic Editor: Valeria Cavallaro

Received: 14 January 2022

Accepted: 9 February 2022

Published: 15 February 2022

Publisher's Note: MDPI stays neutral with regard to jurisdictional claims in published maps and institutional affiliations.

Copyright: (C) 2022 by the authors. Licensee MDPI, Basel, Switzerland. This article is an open access article distributed under the terms and conditions of the Creative Commons Attribution (CC BY) license (https:// creativecommons.org/licenses/by/ $4.0 /)$.
1 Center of Plasma Nano-Interface Engineering, Kyushu University, Fukuoka 819-0395, Japan; siratani@ed.kyushu-u.ac.jp

2 Graduate School of Information Science and Electrical Engineering, Kyushu University, Fukuoka 819-0395, Japan

3 Faculty of Information Science and Electrical Engineering, Kyushu University, Fukuoka 819-0395, Japan; t.okumura@plasma.ed.kyushu-u.ac.jp (T.O.); koga@ed.kyushu-u.ac.jp (K.K.)

4 Center for Novel Science Initiatives, National Institute of Natural Science, Tokyo 105-0001, Japan

5 Institute of Industrial Nanomaterials, Kumamoto University, Kumamoto 860-8555, Japan; douyan@cs.kumamoto-u.ac.jp

6 Faculty of Science and Engineering, Iwate University, Morioka 020-8551, Japan; ktaka@iwate-u.ac.jp (K.T.); takaki@iwate-u.ac.jp (K.T.)

7 Agri-Innovation Center, Iwate University, Morioka 020-8551, Japan

* Correspondence: chem.pankaj@gmail.com

\begin{abstract}
To meet the needs of the hungry population, it is critical to boost agricultural product production while minimizing contaminated waste. The use of two nonthermal technologies, pulsed electric field (PEF) and nonthermal plasma (NTP), is increasing every day. As both PEF and NTP are relatively newer areas, there is limited knowledge about these two technologies and their modes of action. Studies showed that PEF treatment on the plant seeds helps germination and seedling growth. The positive impact of PEF intensity is highly dependent on the seed coat type and plant species. Another nonthermal technology, NTP, affects seed germination, seedling growth, yield, and resilience to abiotic stress when generated at varying pressures with and without different feed gases. Early germination, germination rate, and germination percentage were all improved when the seedlings were treated with NTP. Similarly to the PEF treatment, NTP had a negative or no effect on germination. This review examined the effects of PEF and NTP on seed germination and analyzed the situation and mechanism behind the positive or negative effect. Deactivation of proteins and enzymes to extend the shelf life of beverages is another prominent application of PEF and NTP. The interaction of PEF and NTP with proteins aids in understanding the microscopic mechanism of these technologies. Therefore, we covered in this review the potential structural and functional changes in proteins/enzymes as a result of PEF and NTP, as well as a comparison of the benefits and drawbacks of these two technologies.
\end{abstract}

Keywords: pulsed electric field; nonthermal plasma; seed germination; protein function

\section{Introduction}

The electric field affects plants in both soil and air, as the Earth has an electrified environment maintained by a global circuit. Plant cells contain membrane potential because of ion channels or pumps that allow electric current to flow through them [1]. Various studies have been conducted to study the electric current effect on plants [2]. According to Kotaka et al., the action of ions (positive or negative) in the air can affect variations in plant respiration [3]. Song et al. [4] and Lee et al. [5] showed the impact of air anions on the growth of lettuce and kale, respectively. Seed germination starts with water uptake by the seed and ends with embryonic axis extension. This can take $24-36 \mathrm{~h}$ depending on the germination conditions, followed by radicle elongation [6]. Frequently, plants are facing 
multiple stress that results in decreasing crop yields. Different types of seed treatment techniques were used to increase crop yield under regularly changing environmental stress [7].

Traditional methods, such as cooking, boiling, frying, drying, etc., are frequently used to increase the shelf life of food products [8]. As the world population increases, there is a drastic increase in the consumption of processed foodstuffs that increases chemical additives and thermal processing. This results in inadvertent outcomes such as the formation of toxic compounds, nutrient losses, adverse effects on color and texture, etc. [9]. Nonthermal technologies such as pulsed electric field (PEF) and nonthermal plasma (NTP) have been used to solve these problems.

PEF has shown its importance in the food industry by assisting in different processes such as improvement in oil and juice extraction yields $[10,11]$, secondary metabolites biosynthesis stimulation [12,13], cold pasteurization [14], improvement of nutritional and functional properties of liquid foods [15], seed germination [16], inactivating microorganisms [17], nutrient solution for hydroponic system [18], etc. In general, high-voltage pulses are placed between two electrodes for a brief time; depending upon the voltage supplied, the PEF is categorized into low / moderate-intensity PEF (10-2000 kV/m) and high-intensity PEF (2000-4500 kV/m) [19]. PEF works on the electrical breakdown and electroporation process (formation of holes in the cell membrane and phospholipid bilayers) [15,20]. PEF treatment can result in an interruption in the plant cell wall that can help in improving the extraction process of target compounds [21]. Additionally, the applied electric field can modify the electrical sensitive components and accelerate heat and mass transfer in drying and freezing processes [10]. PEF treatment also alters the proteins'/enzymes' structure [20] and the polarization of molecules with dipole moments (changes can be reversible or irreversible depending upon the molecules and treatment conditions) [15]. Additionally, the effectiveness of PEF treatment depends upon the food matrix ( $\mathrm{pH}$, composition, electrical conductivity) and operating parameters (electric field intensity, pulse polarity, pulse shape, treatment time, and frequency) [22].

Nonthermal plasma (NTP) is a complicated combination of electrons, positive and radicals, negatively charged ions, neutral atoms, and molecules [23]. NTP can produce both ROS and reactive nitrogen species (RNS), and their concentration depends upon the feed gas and plasma parameters. Depending on the concentration of reactive species and the nature of biological species, they have positive and negative impacts on biological systems. The utilization of plasma in agriculture has increased promptly in both pre-harvest and post-harvest cases [7,24,25]. Our group recently increased soil fertility by producing NH4NO3 using NTP that helped in increased germination percentage and yield of radish sprouts [26]. NTP treatments such as direct or indirect treatment showed bactericidal effects through protein oxidation, DNA and cell membrane damage, etc. [27-29]. In contrast, the NTP treatment could activate the plant growth-promoting bacteria [30]. NTP properties make it an ideal technology to treat beverages to increase their shelf life [31].

This review focused on the germination rate/percentage and structural and functional changes in proteins/enzymes after PEF and NTP treatments to elaborate their roles in seed treatment and beverages' preservation.

\section{Germination Rate and Seedling Growth in Plants after the Pulsed Electric Field Treatment}

There are limited reports on the impact of PEF on seed germination and seedling growth, as shown in Table 1. Through this review, we focused on some of the reported work by the various groups on the diverse plant species such as Leaf Lettuce, Barley, Arabidopsis, Kale, Wheat, Chickpea, Mung bean, Bitter gourd, Tomato, Medicago Sativa, Chili, Smallflower Morningglory, and Green Foxtail. 
Table 1. Changes in the growth parameters of plants after PEF treatment.

\begin{tabular}{|c|c|c|c|}
\hline Plant species & Treatment Condition & Results & Ref. \\
\hline $\begin{array}{l}\text { Leaf Lettuce } \\
\text { (Early Impulse) }\end{array}$ & $\begin{array}{l}\text { Electric field intensity } \\
(20-200 \mathrm{kV} / \mathrm{m}) ; \text { pulse repetition } \\
\text { was fixed to } 1 \text { pps. }\end{array}$ & $\begin{array}{l}\text { Growth stimulation for } 20-100 \mathrm{kV} / \mathrm{m} \text { and growth } \\
\text { inhibition }>100 \mathrm{kV} / \mathrm{m} \text { electric field strength. }\end{array}$ & [32] \\
\hline Arabidopsis & $\begin{array}{c}\text { Electric field intensity } \\
(500-5000 \mathrm{kV} / \mathrm{m}) \text {; pulse duration } \\
10-100 \mathrm{~ns} .\end{array}$ & $\begin{array}{l}\text { Growth stimulating and increased leaf area observed } \\
\text { at } 500 \mathrm{kV} / \mathrm{m} \text { at all pulse durations. The } 5000 \mathrm{kV} / \mathrm{m} \\
\text { with a } 10 \text {-ns pulse showed no lethal effect on the } \\
\text { seedlings, while growth inhibition was observed at } \\
5000 \mathrm{kV} / \mathrm{m} \text { for } 100-\mathrm{ns} \text { pulse. }\end{array}$ & [33] \\
\hline $\begin{array}{l}\text { Wheat } \\
\text { (Tritium aestivum) }\end{array}$ & $\begin{array}{l}\text { Electric field intensity } \\
(50-200 \mathrm{kV} / \mathrm{m}) ; \text { pulse width } \\
(20 \mu \mathrm{s}) ; \text { frequency }(5 \mathrm{~Hz}) \\
\text { number of pulses } 100\end{array}$ & $\begin{array}{c}\text { Increased seedling growth at } 140 \mathrm{kV} / \mathrm{m} \text { treatment, } \\
\text { while no increase in seedling growth was observed } \\
\text { at } 50 \mathrm{kV} / \mathrm{m} \text {. PEF-treated seeds treated at } 200 \mathrm{kV} / \mathrm{m} \\
\text { showed high glutathione content and enhanced } \\
\text { antioxidant activity. }\end{array}$ & [34] \\
\hline $\begin{array}{l}\text { Wheat } \\
\text { (Tritium aestivum) }\end{array}$ & $\begin{array}{c}\text { Electric field intensity } \\
(200-600 \mathrm{kV} / \mathrm{m}) ; \text { pulse width } \\
(100 \mu \mathrm{s}) ; \text { frequency }(1 \mathrm{~Hz}) ; \\
\text { number of pulses }(25 \text { and } 50)\end{array}$ & $\begin{array}{l}\text { Increased seed germination and seedling growth } \\
\text { parameters were observed for } 600 \mathrm{kV} / \mathrm{m} \text { at } 50 \text {-pulse } \\
\text { treatment. The increase in soluble proteins, } \\
\text { carotenoids, chlorophylls, total phenolic contents, } \\
\text { etc., for treated seeds' plantlets' juice, compared to } \\
\text { the untreated seeds' plantlets' juice. }\end{array}$ & [35] \\
\hline $\begin{array}{l}\text { Mung bean } \\
\text { (Vigna radiata) }\end{array}$ & $\begin{array}{c}\text { Electric field intensity } \\
(0.8-2.4 \mathrm{kV} / \mathrm{m}) \text {; exposed time } \\
(0.5-2.5 \mathrm{~h})\end{array}$ & $\begin{array}{l}\text { Increased seed germination percentage at static } \\
\text { electric field } 1.2 \mathrm{kV} / \mathrm{m} \text { for } 0.5-\mathrm{h} \text { treatment. } \\
\text { Treatment for } 1-2.5 \mathrm{~h} \text { at } 2.0-\mathrm{kV} / \mathrm{m} \text { static electric field } \\
\text { leads to enhancement of roots' length }(0-89 \%) \text {, stems } \\
\quad(4.8-77 \%) \text {, and leaves }(6.5-59 \%) \text { than control }\end{array}$ & [36] \\
\hline Barley & $\begin{array}{l}\text { Electric field intensity } \\
\qquad(100 \mathrm{kV} / \mathrm{m})\end{array}$ & $\begin{array}{l}\text { The first fraction of the electric separator treatment } \\
\text { changes the viability and germination difference } \\
\text { from the control seed. }\end{array}$ & [37] \\
\hline Barley & 2-9.5 kV; exposure time (35 min) & $\begin{array}{l}\text { An increase in seed germination, germination index, } \\
\text { germination potential, and vigor index was } \\
\text { observed for 3.5- and 5-kV treatment. }\end{array}$ & [38] \\
\hline $\begin{array}{c}\text { Bitter gourd } \\
\text { (Momordica charantia) }\end{array}$ & $\begin{array}{c}\text { Electric field intensity } \\
(30-100 \mathrm{kV} / \mathrm{m}) \text {; exposed time } \\
(20 \mathrm{~min})\end{array}$ & $\begin{array}{c}\text { Seeds treated at } 30-\text { and } 50-\mathrm{kV} / \mathrm{cm} \text { showed a } \\
\text { positive effect on germination, while higher intensity } \\
\text { treatment }(100 \mathrm{kV} / \mathrm{m}) \text { caused the decrease } \\
\text { in germination. }\end{array}$ & [39] \\
\hline $\begin{array}{l}\text { Chickpea } \\
\text { (Cicer arietinum) }\end{array}$ & $\begin{array}{c}\text { Electric field intensity } \\
(27-107 \mathrm{kV} / \mathrm{m}) \text {; treatment time } \\
(15 \mathrm{~min})\end{array}$ & $\begin{array}{c}\text { Seeds' treatment at } \sim 47 \mathrm{kV} / \mathrm{m} \text { for } 15 \mathrm{~min}\left(\text { at } 13{ }^{\circ} \mathrm{C}\right) \\
\text { caused increased mean germination time and } \\
\text { improved root and shoot length. }\end{array}$ & [40] \\
\hline $\begin{array}{l}\text { Chickpea } \\
\text { (Cicer arietinum) }\end{array}$ & $\begin{array}{l}3-12 \mathrm{~V} \text {; induced for } 10 \mathrm{~min} \text { for } \\
100 \text { days }\end{array}$ & $\begin{array}{l}\text { 3-V and } 6-\mathrm{V} \text { treatment results in early seed } \\
\text { germination, while no difference for control and } 12 \mathrm{~V} \text {. } \\
\text { The increase in the plant heights observed for } 3,6,9 \text {, } \\
\text { and } 12 \mathrm{~V} \text { as } 25.5,30.5,11.8 \text {, and } 17.1 \% \text {, respectively. } \\
\text { The increase in root length by } 28.6,24.0 \text {, and } 3.0 \% \\
\text { were under treatment at } 3,6 \text {, and } 12 \mathrm{~V} \text {, respectively. } \\
\text { Leaf numbers were higher under } 3-, 6-, 9-\text {, and } 12-\mathrm{V} \\
\text { treatment as } 25.3,25.2,15 \text {, and } 19.3 \% \text {, respectively. }\end{array}$ & [41] \\
\hline Tomato & $\begin{array}{l}\text { Electric field intensity }(1000-3000 \\
\mathrm{kV} / \mathrm{m}) ; \text { frequency }(50 \mathrm{~Hz}) \\
\text { exposure time }(10-30 \mathrm{~s})\end{array}$ & $\begin{array}{l}2000-\mathrm{kV} / \mathrm{m} \text { treatment for } 20 \mathrm{~s} \text { caused } 100 \% \\
\text { germination, whereas } 76 \% \text { for control. The weight of } \\
\text { tomato seedlings was increased for treated seeds } \\
\text { than untreated ones. }\end{array}$ & [42] \\
\hline
\end{tabular}


Table 1. Cont.

\begin{tabular}{|c|c|c|c|}
\hline Plant species & Treatment Condition & Results & Ref. \\
\hline Medicago Sativa & 1-7 V; exposure time (2.5 and $5 \mathrm{~h}$ ) & $\begin{array}{l}\text { The highest germination rate was observed after } \\
\text { treatment of seeds for } 5 \mathrm{~h} \text { with } 3 \mathrm{~V} \text {. The lowest } \\
\text { germination rate was observed for } 4-\mathrm{V} \text { treatment for } \\
2.5 \mathrm{~h} .1 \mathrm{~V} \text { at } 2.5 \text { - and } 5 \text {-h treatment caused no } \\
\text { significant effect than control samples. The } \\
\text { maximum average root length was obtained for } 1-\mathrm{h} \\
\text { treatment at } 4 \mathrm{~V} \text {. The } 7-\mathrm{V} \text { administration could } \\
\text { effectively enhance the germination process with } \\
\text { increased crop yield. }\end{array}$ & {$[43]$} \\
\hline $\begin{array}{c}\text { Chili } \\
\text { (Capsicum annuum) }\end{array}$ & $\begin{array}{l}\text { Combination of } 250-1000 \mathrm{G} \text { and } \\
\qquad 100-400 \mathrm{~mA}\end{array}$ & $\begin{array}{l}\text { The highest germination was observed during the } \\
\text { combination seed treatment (magnetic field (1000 G) } \\
\text { for } 30 \mathrm{~min}+\text { electric field ( } 100 \mathrm{~mA}) \text { for } 1 \mathrm{~min}) \text {, and } \\
\text { separate treatment of } 300-\mathrm{mA} \text { electric field for } 1 \mathrm{~min} \text {. } \\
\text { A high magnetic field enhanced germination } \\
\text { capacity and seedling characteristics. }\end{array}$ & {$[44]$} \\
\hline $\begin{array}{l}\text { Smallflower } \\
\text { Morningglory } \\
\text { [Jacquemontia tamnifolia } \\
\text { (L.) Briseb.] and Green } \\
\text { Foxtail [Setaria viridis } \\
\text { (L.) Beauv.]. }\end{array}$ & $\begin{array}{l}\text { Single electric pulse of } 4-6-k V \\
\text { and } 60-80-k V \text { repetitive pulse. }\end{array}$ & $\begin{array}{l}\text { Seedling emergence was higher }(99 \%) \text { in } \\
\text { Smallflower Morningglory seeds treated with a } \\
\text { 10-Hz repetitive pulse for } 5 \mathrm{~s} \text { than in seeds exposed } \\
\text { to } 10 \text { repeating single pulses }(87 \%) \text { or untreated } \\
\text { seeds }(91 \%) \text {. There were no variations in Green } \\
\text { Foxtail seeds treated with any intensity of PEF. }\end{array}$ & {$[45]$} \\
\hline $\begin{array}{l}\text { Two kale cultivars } \\
\text { (Brassica oleracea var. } \\
\text { acephala cv. TBC and } \\
\text { Abundance) }\end{array}$ & $\begin{array}{l}\text { Electric field intensity } \\
(8.6-58.8 \mathrm{~V} / \mathrm{m}) \text {; electric currents } \\
(10-100 \mathrm{~mA})\end{array}$ & $\begin{array}{l}\text { PEF treatment results in higher fresh and dry } \\
\text { weights than the control for 50-mA current. After } \\
\text { treatment, there was an increase in calcium, total } \\
\text { phenolic compounds, and antioxidant level. }\end{array}$ & {$[16]$} \\
\hline
\end{tabular}

Wheat seeds treated with PEF at $140 \mathrm{kV} / \mathrm{m}$ (100 pulses) [34] and $600 \mathrm{kV} / \mathrm{m}$ (50 pulses) [35] results in increased seedling growth. PEF treatment at $200 \mathrm{kV} / \mathrm{m}$ (100 pulses) decreases coleoptile and primary leaf growth [34]. The increase in glutathione content and antioxidant enzyme activity was observed at $200 \mathrm{kV} / \mathrm{m}$ (100 pulses), while no significant change was observed at $140-\mathrm{kV} / \mathrm{m}$ (100 pulses) treatment [34];600-kV/m (50 pulses) treatment resulted in a significant increase in soluble proteins, carotenoids, chlorophylls, total phenolic contents, etc. for treated seeds' plantlets' juice, compared to the untreated seeds' plantlets' juice [35]. This shows that low-intensity PEF with fewer pulses or high-intensity PEF with fewer pulses significantly contributed to wheat germination and seedling growth than high-intensity PEF with high pulses.

Barley seeds' treatment with electric field $100 \mathrm{kV} / \mathrm{m}$ resulted in a significant increase in germination for the first fraction of treatment while it declined for the second fraction of the electric field [37]. In another study, barley seeds, when treated with a high-voltage electric field ( 3.5 and $5 \mathrm{kV}$ ) for 35 min continued up to 10 days, resulted in significant increase in seed germination. At the same time, no positive effect was observed for $0,2,6.5,8$, and $9.5 \mathrm{kV}$. This shows that medium voltage is better for seed germination, and high or low voltage is ineffective to promote germination [38]. However, barley seeds treated with $120-\mathrm{kV} / \mathrm{m}$ electric fields result in radicle elongation without affecting the gross metabolic activity and $\alpha$-amylase concentration decreased for treated seeds [46]. Chickpea seeds' treatment of $\sim 47-\mathrm{kV} / \mathrm{m}$ PEF for $15 \mathrm{~min}$ caused increased mean germination time [40]. In another study, Chickpea seeds treated with an electric field ( $3 \mathrm{~V}$ and $6 \mathrm{~V}$ induced for $10 \mathrm{~min}$ for 100 days) showed the enhanced rate of seed germination, while no change was observed for $12 \mathrm{~V}$, although a decrease in seedling root and shoot length was observed for $12-\mathrm{V}$ treatment as compared to $3 \mathrm{~V}$ and $6 \mathrm{~V}$ treatment [41].

The above data showed that low-intensity electric field has no significant effect on seed germination, seedling growth, and biochemical effect. In contrast, high electric field intensity causes a negative impact on seed germination, but it significantly affects the 
biochemical changes in the plants. At the same time, the medium electric field strength is best for germination and seedling growth. However, the electric field strength value for medium and high can depend upon the seed coat thickness. The increased seedling emergence of seeds under particular PEF treatments can be attributed to hard seed coats. Seeds can absorb water when the seed coat is damaged by PEF treatment, allowing for water imbibition, whereas seeds lacking solid seed coats result in the embryo's damage, which causes decreased seedling emergence with the same amount of PEF intensity [45]. Another possibility is that the electric field can activate the ion transport that helps in improving the nutrient uptake [16]. It is worth noting that significant changes in the biochemical properties were observed (mainly at high electric field strength) that showed no direct correlation with the germination of seeds, although the change in biochemical properties, such as protein level, antioxidant level, etc., can influence plant growth and yield. Protein/enzyme plays an essential role in plant growth, and the deactivation of enzymes can improve the shelf life and quality of beverages such as juices, which are mentioned in the following section.

\section{Impact of the PEF on the Proteins'/Enzymes' Conformation and Activity}

Changes in the conformation and function of proteins/enzymes are shown in Table 2.

Table 2. Conformational and functional changes in proteins/enzymes after PEF treatment.

\begin{tabular}{|c|c|c|c|}
\hline Protein/Enzymes & Treatment Condition & Results & Ref. \\
\hline Soybean protein isolate & $\begin{array}{l}\text { Electric field intensity }(3000 \mathrm{kV} / \mathrm{m}) \\
\text { pulse width }(2 \mu \mathrm{s}) ; \text { pulse cycle } \\
(0.001-0.009 \mathrm{~s}) ; \text { frequency }(400 \mathrm{~Hz})\end{array}$ & $\begin{array}{c}\text { Increased random coils and } \beta \text {-sheets and a } \\
\text { decrease in } \alpha \text {-helix after PEF treatment } \\
\text { were obtained. }\end{array}$ & [47] \\
\hline Soybean protein isolate & $\begin{array}{l}\text { Electric field intensity }(0-5000 \mathrm{kV} / \mathrm{m}) \\
\text { pulse width }(40 \mu \mathrm{s}) ; \text { frequency } \\
(1.0 \mathrm{kHz})\end{array}$ & $\begin{array}{l}\text { At } 3500-\mathrm{kV} / \mathrm{m} \text { intensity, the conversion of } \beta \text {-turn } \\
\text { to } \alpha \text {-helix happened. There was an increase and } \\
\text { decrease in anti-parallel } \beta \text {-sheets and } \beta \text {-sheets' } \\
\text { contents at high pulse intensity, respectively. }\end{array}$ & [48] \\
\hline Soybean lipoxygenase & $\begin{array}{l}\text { Electric field intensity }(2000-4200 \\
\mathrm{kV} / \mathrm{m}) ; \text { pulse width }(1-5 \mathrm{~s}) ; \text { frequency } \\
(100-600 \mathrm{~Hz}) \text {; treatment time }(1036 \mu \mathrm{s}) \text {. }\end{array}$ & $\begin{array}{c}\text { The maximum inactivation of } 88 \% \text { was achieved } \\
\text { at } 4200-\mathrm{kV} / \mathrm{m} \text { electric fields at a pulse frequency } \\
\text { of } 400 \mathrm{~Hz} \text { and pulse width of } 2 \mu \text { s treated for } \\
1036 \mu \mathrm{s} \text { at } 25^{\circ} \mathrm{C} \text {. }\end{array}$ & [49] \\
\hline Soybean lipoxygenase & $\begin{array}{c}\text { Electric field intensity }(2000-4200 \\
\mathrm{kV} / \mathrm{m}) \text {; treatment time }(25-100 \mu \mathrm{s}) ; \\
\text { pre-treatment temperature }\left(23-50^{\circ} \mathrm{C}\right) \text {. }\end{array}$ & $\begin{array}{l}\text { The highest inactivation level of } 84.5 \% \text { was } \\
\text { observed at } 4000 \mathrm{kV} / \mathrm{m} \text { with preheating to } 50{ }^{\circ} \mathrm{C} \text {, } \\
\text { and treatment for } 100 \mu \mathrm{s} \text {. }\end{array}$ & [50] \\
\hline Horseradish peroxidase & $\begin{array}{l}\text { Electric field intensity (500-2500 } \\
\mathrm{kV} / \mathrm{m}) ; \text { pulse width }(1.5 \mu \mathrm{s}) ; \text { frequency } \\
\text { (10 Hz); pulses }(207-1449) \text {. }\end{array}$ & $\begin{array}{l}\text { Loss of } \alpha \text {-helix content at } 2200 \mathrm{kV} / \mathrm{m} \text { for } \\
87 \text { pulses and the relative fluorescence intensity } \\
\text { increased with increased electric field strength } \\
\text { from } 2000 \text { to } 2500 \mathrm{kV} / \mathrm{m} \text {. The relative activity } \\
\text { reduced to } 16.7 \text { and } 34.7 \% \text { for electric field } \\
\text { strength of } 2500 \mathrm{kV} / \mathrm{m} \text { ( } 207 \text { pulses) and } \\
2200 \mathrm{kV} / \mathrm{m}(1214 \text { pulses), respectively }\end{array}$ & [51] \\
\hline Lysozyme & $\begin{array}{l}\text { Electric field intensity }(2500-3500 \\
\mathrm{kV} / \mathrm{m}) ; \text { pulse width }(2 \mu \mathrm{s}) \text {; frequency } \\
(1000 \mathrm{~Hz}) \text {; treatment time }(0-1200 \mu \mathrm{s}) \text {. }\end{array}$ & $\begin{array}{c}\text { The unfolding of lysozyme tertiary structure } \\
\text { induced by } 3500-\mathrm{kV} / \mathrm{m} \text { treatment for } 1200 \mu \mathrm{s} \text {. } \\
\text { The lysozyme activity was reduced by } 19.2,27.7 \text {, } \\
\text { and } 38.1 \% \text { for } 25,30 \text {, and } 35 \mathrm{kV} / \mathrm{cm} \text {, respectively, } \\
\text { for } 1200 \mu \mathrm{s} \text {. }\end{array}$ & [52] \\
\hline$\beta$-lactoglobulin & $\begin{array}{c}\text { Electric field intensity }(1250 \mathrm{kV} / \mathrm{m}) ; \\
\text { number of pulses }(1-10) ; \text { time between } \\
\text { pulses }(15 \mathrm{~s}) .\end{array}$ & $\begin{array}{c}\text { The peak temperature of } \beta \text {-lactoglobulin } \\
\text { decreased to } 71.0 \pm 2.0 \text { from } 75.4 \pm 0.7 \text { (control) } \\
\text { at } 10 \text { pulses. }\end{array}$ & [53] \\
\hline
\end{tabular}


Table 2. Cont.

\begin{tabular}{|c|c|c|c|}
\hline Protein/Enzymes & Treatment Condition & Results & Ref. \\
\hline Ovalbumin & $\begin{array}{c}\text { Electric field intensity } \\
(2500-3500 \mathrm{kV} / \mathrm{m}) ; \text { pulse width }(5 \mu \mathrm{s}) ; \\
\text { frequency }(20 \mathrm{~Hz}) ; \text { treatment time } \\
(60-240 \mu \mathrm{s})\end{array}$ & $\begin{array}{l}\text { The free sulphydryl }(-\mathrm{SH}) \text { protein content was } \\
\text { significantly increased after treatment in the } \\
\text { range of } 2000-2500 \mathrm{kV} / \mathrm{m} \text {. The increase and } \\
\text { decrease in free } \mathrm{SH} \text { content at } 3500 \mathrm{kV} / \mathrm{m} \text { for } \\
0-60 \mu \text { s and } 120-240 \mu \mathrm{s} \text {, respectively. The } \\
\text { decrease in } \alpha \text {-helix and slightly increased } \beta \text {-sheet } \\
\text { contents for a long treatment time of } 120-180 \mu \mathrm{s} \\
\text { at } 3500 \mathrm{kV} / \mathrm{m} \text {. However, at } 3500 \mathrm{kV} / \mathrm{m} \text {, } \\
\text { treatment for } 60 \mu \text { sid not significantly alter the } \\
\text { secondary structure of the protein. }\end{array}$ & {$[54]$} \\
\hline
\end{tabular}

Electric field intensity $(3420 \mathrm{kV} / \mathrm{m})$;
Pepsin (800 pps for 0-603 $\mu$ s).

Electric field intensity (2520-3560

$\mathrm{kV} / \mathrm{m})$; pulse width (2 $\mu \mathrm{s})$; pulse

Pepsin repetition $(200 \mathrm{~Hz})$; treatment time

$(0-500 \mu \mathrm{s})$.

Canola protein

10-35 kV: frequency $(600 \mathrm{~Hz})$; pulse width $(8 \mu \mathrm{s})$; treatment time (180 s).

Peroxidase in

Electric field intensity $(3500 \mathrm{kV} / \mathrm{m})$;

Tomato juice

frequency $(50-250 \mathrm{~Hz} \mathrm{~Hz})$; pulse width

(1-7 $\mu \mathrm{s})$; treatment time $(1000-2000 \mu \mathrm{s})$.

The aggregation and inactivation of pepsin were reported.

Self-aggregation at $3560 \mathrm{kV} / \mathrm{m}$ for $300 \mu \mathrm{s}$ and increased as the treatment increases. The

decreased activity was observed as treatment time increased.

Decrease in $\alpha$-helices and $\beta$-turns, but increase

in the number of random coils and also induced protein aggregation

Reduced peroxidase activity was most effective for prolonging the treatment time of $2000 \mu \mathrm{s}$ at

Peroxidase and

Polyphenoloxidase in apple juice

Electric field intensity (2000-4000

$\mathrm{kV} / \mathrm{m})$; treatment time $(25-100 \mu \mathrm{s})$; pre-treatment temperatures $\left(23-50{ }^{\circ} \mathrm{C}\right)$.

Electric field intensity (2500-3500

Polyphenoloxidase in grape juice

$\mathrm{kV} / \mathrm{m})$; pulse width $(4 \mu \mathrm{s})$; frequency

(200-1000 Hz); treatment time (1-5 ms).

Electric field intensity (500-3500

Pectin methyl esterase in orange juice

$\mathrm{kV} / \mathrm{m})$; pulse width $(4 \mu \mathrm{s})$; frequency (200 Hz); treatment time (100-1500 $\mu \mathrm{s})$.
$\mathrm{kV} / \mathrm{m})$; treatment time $(25-100 \mu \mathrm{s})$; red grapefruit juice pre-treatment temperatures $\left(23-50{ }^{\circ} \mathrm{C}\right)$.

$\alpha$-amylase

Electric field intensity $(250-1250 \mathrm{kV} / \mathrm{m})$; pulse width $(10 \mu \mathrm{s})$; input energy into the reactor per pulse $(0.02-0.6 \mathrm{~J})$. $\alpha$-amylase, carboxypeptidase glucoamylase, and acid
Electric field intensity $(4000 \mathrm{kV} / \mathrm{m})$; voltage $(4 \mathrm{kV})$; pulse width $(10 \mu \mathrm{s})$; frequency $(1 \mathrm{~Hz})$; the current was approximately $9.5 \mathrm{~A}$ and $27.5 \mathrm{~A}$ at $4{ }^{\circ} \mathrm{C}$ and $25^{\circ} \mathrm{C}$, respectively. $200 \mathrm{~Hz}$. The bipolar mode showed more effectiveness than monopolar mode for enzyme inactivation.

The decreased residual activity with increased treatment time and electric field strength.

At $3500 \mathrm{kV} / \mathrm{m}$ and $630 \mathrm{~Hz}$ no polyphenoloxidase activity was detected, while $58.13 \%$ of depletion was achieved at $3020 \mathrm{kV} / \mathrm{m}$ and $1000 \mathrm{~Hz}$ for 5-ms treatment.

The maximum inactivation reached about $80 \%$ when juice samples were processed at 3500

$\mathrm{kV} / \mathrm{m}$ for $1500 \mu \mathrm{s}$ at $200 \mathrm{~Hz}$ without exceeding $37.5^{\circ} \mathrm{C}$.

$96.8 \%$ inactivation of pectin methyl esterase in red grapefruit juice was obtained with a $50-{ }^{\circ} \mathrm{C}$ preheating and $4000-\mathrm{kV} / \mathrm{m}$ PEF treatment time for $100 \mu s$.

The fluorescence peak showed redshift with decreased intensity for PEF intensity higher than $750 \mathrm{kV} / \mathrm{m}$. The reduction in $\alpha$-amylase activity increased at a higher electric field.

Residual activities of $\alpha$-amylase, glucoamylase, and acid carboxypeptidase decreased at $4{ }^{\circ} \mathrm{C}$ for 300 pulses but were not affected for 900 pulses. The $\alpha$-amylase activity decreased as the number of pulses increases at $25^{\circ} \mathrm{C}$, but no change was obtained at $35^{\circ} \mathrm{C}$. Glucoamylase activity showed significant decreases for 300 pulses at $25^{\circ} \mathrm{C}$ compared to $4{ }^{\circ} \mathrm{C}$. Acid carboxypeptidase activity significantly increased by 300 -pulse treatment at $25^{\circ} \mathrm{C}$. 
Soybean protein treated with a 3000-kV/m electric field increases random coils and $\beta$-sheets and decreases in $\alpha$-helix [47]. The PEF treatment changes the vibrational peaks of S-S and C-C, as indicated by the disturbance in sulfhydryl's and disulfide bonds. PEF treatments influenced the hydrophobicity of protein by changing the tyrosine vibration frequency [47]. Another study showed $3500-\mathrm{kV} / \mathrm{m}$ intensity of PEF treatment on soybean protein resulted in conversion of $\beta$-turn to $\alpha$-helix and induced a change in the orientation of the $\alpha$-helix dipole moment. Additionally, at high pulse intensity, there was an increase and decrease in anti-parallel $\beta$-sheets' and $\beta$-sheets' contents, respectively [48]. These structural changes are due to a change in the bond vibration of $\mathrm{C}-\mathrm{O}, \mathrm{C}-\mathrm{O}-\mathrm{H}, \mathrm{C}-\mathrm{O}-\mathrm{C}, \mathrm{C}-\mathrm{H}$, and N-H by PEF treatment [48]. Soybean lipoxygenase protein treated with $4200 \mathrm{kV} / \mathrm{m}$ caused maximum inactivation of $88 \%$ after $1036 \mu$ s [49]. Another group achieved the $84.5 \%$ inactivation of soybean lipoxygenase after a $4000-\mathrm{kV} / \mathrm{m}$ treatment with preheating to $50{ }^{\circ} \mathrm{C}$ after $100 \mu \mathrm{s}$ [50]. This shows that preheating can speed up the PEF-induced enzyme deactivation rate.

Inactivation of polyphenol oxidase was stronger than peroxidase in apple juice, showing that inactivation strongly depends upon the protein structure [59]. Some studies revealed the extent of deactivation of peroxidase in tomato juice [58] and polyphenol oxidase in grape juice [60] after PEF treatment, depending upon the intensity of the electric field and treatment time. Pectin methyl esterase protein in orange juice and red grapefruit juice treated with PEF gives rise to inactivation [61,62]. Pectin methyl esterase protein in orange juice showed a maximum inactivation of about $80 \%$ when juice samples were processed at $3500 \mathrm{kV} / \mathrm{m}$ without exceeding temperature to $37.5^{\circ} \mathrm{C}$ [61]. Conversely, $96.8 \%$ inactivation of pectin methyl esterase in red grapefruit juice was obtained with a $50-{ }^{\circ} \mathrm{C}$ preheating and $4000-\mathrm{kV} / \mathrm{m}$ PEF treatment [62]. Hence, pectin methyl esterase inactivation increases as the electric field strength, treatment times, and preheating temperatures increase. The distortion of the $\alpha$-amylase structure and activity was obtained when treated for the higher electric field $(>750 \mathrm{kV} / \mathrm{m})$. These changes are not the result of the increase in temperature by the Joule's effect but due to modification in the tryptophan residues [63]. Another study supported the above statement as $\alpha$-amylase activity decreased as pulses increased at $25^{\circ} \mathrm{C}$ [64].

The above studies clearly showed that a higher electric field is required to deactivate the enzymes. Still, the extent of the deactivation depends upon the enzyme structure and treatment time while also being influenced by the preheating treatment.

NTP is another nonthermal treatment that has gained attention in seed germination and enzyme deactivation.

\section{Effect of NTP on Seed Germination}

NTP treatment on the plant seeds affects seed germination, seedling growth, and yield of the plant. Our previous reviews described the plasma action on seedling growth and probable mechanism [7,24]. The current study focused on the latest results on seed germination using NTP, as shown in Table 3.

Table 3. Effect of NTP on seed germination.

\begin{tabular}{|c|c|c|c|}
\hline Plant Species & Plasma Device & Seed Germination & Ref. \\
\hline $\begin{array}{c}\text { Rice } \\
(\text { Oryza sativa) }\end{array}$ & $\begin{array}{l}\text { Scalable dielectric barrier discharge } \\
\text { plasma; pressure }(101,325 \mathrm{~Pa}) \text {; voltage } \\
(7.96 \mathrm{kV}) \text {; frequency }(9.2 \mathrm{kHz}) \text {; power } \\
(2.17 \mathrm{~W}) \text {; treatment time }(10 \mathrm{~s} \text { or } 60 \mathrm{~s} \text { for } \\
\text { the total } 3 \mathrm{~min}) .\end{array}$ & $\begin{array}{l}\text { The heat-stressed rice seeds treated with plasma } \\
\text { showed a higher germination rate than without } \\
\text { plasma heat-stressed seeds. }\end{array}$ & [65] \\
\hline $\begin{array}{c}\text { Rice } \\
(\text { Oryza Sativa) }\end{array}$ & $\begin{array}{l}\text { Low-pressure dielectric barrier } \\
\text { discharge plasma; voltage }(3-5 \mathrm{kV}) \text {; } \\
\text { frequency }(3-8 \mathrm{kHz}) \text {; pressure }(1333 \mathrm{~Pa}) \text {; } \\
\text { power }(\sim 45 \mathrm{~W}) \text {; gas }(\mathrm{Ar}+\mathrm{Air}) .\end{array}$ & $\begin{array}{c}\text { After 8-min plasma treatment, the maximum } \\
\text { seed germination was } 9.72 \% \text { higher than } \\
\text { control seeds. }\end{array}$ & [66] \\
\hline
\end{tabular}


Table 3. Cont.

\begin{tabular}{|c|c|c|c|}
\hline Plant Species & Plasma Device & Seed Germination & Ref. \\
\hline $\begin{array}{c}\text { Rice } \\
(\text { Oryza Sativa) }\end{array}$ & $\begin{array}{l}\text { Hybrid cold plasma }(\mathrm{HCP}) \text { (array of } \\
10 \times 70 \text { electrodes }(\sim 1400 \text { tips in total) } \\
\left.\text { covering } \sim 30 \mathrm{~cm}^{2}\right) \text {; frequency } \\
(\sim 700 \mathrm{~Hz}) \text {; voltage }(\sim 14 \mathrm{kV}) \text {; gas }(\mathrm{Ar})\end{array}$ & $\begin{array}{l}\text { The final germination percentage of the treated } \\
\text { rice seeds was } \sim 98 \% \text {, whereas that of the } \\
\text { nontreated seeds was } \sim 90 \% \text {. }\end{array}$ & [67] \\
\hline $\begin{array}{c}\text { Rice } \\
\text { (Oryza sativa) }\end{array}$ & $\begin{array}{l}\text { Atmospheric pressure multi-pin } \\
\text { plasma generator; pressure }(101,325 \mathrm{~Pa}) \\
\text { voltage }(18,22,26 \text {, and } 30 \mathrm{kV})\end{array}$ & $\begin{array}{l}\text { Germination rate increased by } 6-22 \% \text { for } \\
\text { plasma-treated samples than control. The } \\
\text { average length of root, shoot, seedling, and dry } \\
\text { weight was enhanced by } 2,1.49,1.41 \text {, and } \\
1.08 \text { times, respectively, than control. }\end{array}$ & [68] \\
\hline $\begin{array}{c}\text { Taikeng } 9 \text { (TK9) brown } \\
\text { rice }\end{array}$ & $\begin{array}{l}\text { Low-pressure plasma; pressure } \\
\text { (800 Pa); voltage }(1-3 \mathrm{kV}) \text {; discharge } \\
\text { gas (Air); treatment time (10 min) }\end{array}$ & $\begin{array}{l}\text { Increased germination rate, water uptake, } \\
\text { seedling length, and GABA levels at } 3 \mathrm{kV} \text { for } \\
10 \text {-min plasma treatment. }\end{array}$ & [69] \\
\hline $\begin{array}{c}\text { Radish } \\
\text { (Raphanus sativus) }\end{array}$ & $\begin{array}{l}\text { Scalable dielectric barrier discharge } \\
\text { plasma; pressure }(101,325 \mathrm{~Pa}) ; \\
\text { frequency }(14.4 \mathrm{kHz}) \text {; power density } \\
\left(3.05 \mathrm{~W} / \mathrm{cm}^{2}\right) \text {; treatment time }(3 \mathrm{~min}) \text {. }\end{array}$ & $\begin{array}{l}\text { Maximal germination percentage increased by } \\
8 \% \text { for gray-colored seeds while not influencing } \\
\text { the brown seeds harvested in the same year. }\end{array}$ & [70] \\
\hline $\begin{array}{c}\text { Radish } \\
\text { (Raphanus sativus) }\end{array}$ & $\begin{array}{l}\text { Scalable dielectric barrier discharge } \\
\text { plasma: frequency }(10 \mathrm{kHz}) \text {; pressure } \\
(101,325 \mathrm{~Pa}) \text {; voltage }(9.2 \mathrm{kV}) \text {; current } \\
(0.2 \mathrm{~A}) \text {; treatment time }(180 \mathrm{~s}) .\end{array}$ & $\begin{array}{l}\text { The seeds' treatment at } x=5 \text { and } y=3 \mathrm{~mm} \\
\text { resulted in } 250 \% \text { growth enhancement. }\end{array}$ & [71] \\
\hline $\begin{array}{c}\text { Radish } \\
\text { (Raphanus sativus) }\end{array}$ & $\begin{array}{l}\text { Scalable dielectric barrier discharge } \\
\text { plasma; frequency }(10 \mathrm{kHz}) \text {; pressure } \\
(101,325 \mathrm{~Pa}) \text {; voltage }(9.2 \mathrm{kV}) \text {; current } \\
(0.2 \mathrm{~A}) \text {; gases }\left(\mathrm{NO}(10 \%)+\mathrm{N}_{2}, \mathrm{Air}, \mathrm{O}_{2}\right. \\
\left.\mathrm{N}_{2} \text {, and } \mathrm{He}\right) \text {; treatment time }(180 \mathrm{~s})\end{array}$ & $\begin{array}{l}\text { The growth enhancement was observed for } \mathrm{O}_{2} \\
\text { Air, and } \mathrm{NO}(10 \%)+\mathrm{N}_{2} \text { gases' plasma, but no } \\
\text { considerable contribution was noticed for } \mathrm{N}_{2} \\
\mathrm{He} \text {, and Ar plasma. Moreover, humid air plasma } \\
\text { irradiation was more effective in growth } \\
\text { enhancement than dry. }\end{array}$ & [72] \\
\hline $\begin{array}{c}\text { Radish } \\
\text { (Raphanus sativus) }\end{array}$ & $\begin{array}{l}\text { Plasma torch; voltage }(7-10 \mathrm{kV}) ; \\
\text { frequency }(12 \mathrm{kHz}) ; \text { gas }\left(\text { Air and } \mathrm{O}_{2}\right) \\
\text { treatment time }(60 \mathrm{~min}) .\end{array}$ & $\begin{array}{c}\text { The total length (stem and root length) increased } \\
\text { by } 1.6 \text { and } 1.2 \text { times for } \mathrm{O}_{2} \text { and Air feed gas } \\
\text { plasma treatment than control. }\end{array}$ & [73] \\
\hline $\begin{array}{c}\text { Radish } \\
\text { (Raphanus sativus) }\end{array}$ & $\begin{array}{l}\text { Plasma jet; power }(90 \text { and } 140 \mathrm{~W}) ; \\
\text { pressure }(101,325 \mathrm{~Pa}) ; \text { treatment time } \\
\quad(2,4 \text {, and } 6 \mathrm{~min}) \text {; gas }(\mathrm{Ar}) .\end{array}$ & $\begin{array}{l}\text { Plasma treatment had a positive effect on } \\
\text { germination enhancement. An increase in total } \\
\text { mass observed at } 140 \mathrm{~W} \text { than } 90 \mathrm{~W} \text {. Plasma } \\
\text { treatment at } 140-\mathrm{W} \text { power increased total mass } \\
\text { by } 9-12 \% \text { and average length by } 3 \mathrm{~cm} \text { compared } \\
\text { to untreated seeds. }\end{array}$ & [74] \\
\hline $\begin{array}{c}\text { Radish } \\
\text { (Raphanus sativus) }\end{array}$ & $\begin{array}{l}\text { Radio-frequency low-pressure plasma; } \\
\text { pressure }(100 \mathrm{~Pa}) \text {; power }(50 \mathrm{~W}) ; \\
\text { frequency }(13.56 \mathrm{MHz}) \text {; feed gases }\left(\mathrm{O}_{2}\right. \\
\left.\text { and } \mathrm{N}_{2}\right) \text {; treatment time }(30 \mathrm{~min}) .\end{array}$ & $\begin{array}{c}\text { The average length of the sprouts increased by } \\
60 \% \text { for } \mathrm{O}_{2} \text { plasma than control, while no change } \\
\text { was observed for } \mathrm{N}_{2} \text { plasma compared } \\
\text { to control. }\end{array}$ & [75] \\
\hline $\begin{array}{c}\text { Radish } \\
\text { (Raphanus sativus) }\end{array}$ & $\begin{array}{l}\text { Radio-frequency low-pressure plasma; } \\
\text { pressure }(40 \mathrm{~Pa}) \text {; power }(50 \mathrm{~W}) ; \\
\text { frequency (13.56 MHz); feed gases (Air); } \\
\text { treatment time (10-90 min). }\end{array}$ & $\begin{array}{l}\text { Plasma treatment increased germination rate and } \\
\text { growth enhancement. }\end{array}$ & [76] \\
\hline $\begin{array}{c}\text { Centipedegrass } \\
\text { (Eremochloa ophiuroides) }\end{array}$ & $\begin{array}{l}\text { Radio-frequency discharge HD-2N cold } \\
\text { plasma apparatus; pressure }(150 \mathrm{~Pa}) \\
\text { frequency }(13.56 \mathrm{MHz}) ; \text { feed gas }(\mathrm{He}+ \\
\text { Air }(8: 1, v / v)) ; \text { power }(0-210 \mathrm{~W}) \\
\text { treatment time }(15 \mathrm{~s})\end{array}$ & $\begin{array}{l}\text { The germination rate was increased by } 13.95 \text {, } \\
20.93 \text {, and } 12.39 \% \text {, by } 90-, 120-, \text { and } 180-\mathrm{W} \\
\text { treatments, respectively, compared to control. } \\
\text { However, no substantial difference was observed } \\
\text { when seeds were treated at } 30-, 60-, 150-, \text { or } \\
210-W \text { plasma compared to control. }\end{array}$ & [77] \\
\hline $\begin{array}{l}\text { Bambara groundnut } \\
\text { (Vigna subterranean) }\end{array}$ & $\begin{array}{l}\text { Radiofrequency low-pressure plasma; } \\
\text { pressure }(\sim 46 \mathrm{~Pa}) \text {; frequency } \\
(13.56 \mathrm{MHz}) \text {; treatment time }(10-30 \mathrm{~s}) \text {. }\end{array}$ & $\begin{array}{c}\text { Germination was improved by } 22 \% \text { when seeds } \\
\text { were treated at } 10 \mathrm{~W} \text { for } 10 \mathrm{~s} \text {. Treatment at } 10 \mathrm{~W} \\
\text { for } 20 \text { and } 30 \mathrm{~s} \text { caused enhanced germination } \\
\text { percentage by } 15 \text { and } 3 \% \text {, and } 30 \text {-W treatment for } \\
10 \mathrm{~s} \text { showed increments in germination } \\
\text { percentage by } 7 \% \text {. }\end{array}$ & [78] \\
\hline
\end{tabular}


Table 3. Cont.

\begin{tabular}{cc}
\hline Plant Species & Plasma Device \\
\hline Barley (Hordeum vulgare), & Microwave-driven discharge plasma; \\
Rape (Brassica napus), & feed gas (Air); frequency $(2.45 \mathrm{GHz}) ;$ \\
Lupine (Lupinus & supplied power $(4 \mathrm{~kW})$. \\
angustifolius) & \\
\hline
\end{tabular}

Seed Germination

Ref.

There were negative impacts on maximum germination at certain treatment conditions, depending on the tested plant species.
Surface dielectric barrier discharge

Barley

(Hordeum vulgare) (SDBD) plasma; frequency $(14.4 \mathrm{kHz})$; pressure $(101,325 \mathrm{~Pa})$; voltage $(8 \mathrm{kV})$; average power $(51.7 \mathrm{~W})$; treatment time (6 min).
It accelerated the early growth of barley sprouts. The fresh weight of barley seedlings increased by $137.5 \%$ on the 9 th day after the plasma treatment. The treatment enhanced the primary metabolites' (soluble sugars and free amino acids) and secondary metabolites' contents (saponarin, GABA, and policosanols).

There was no significant change in germinated seeds' quantity and plant length for control or plasma-treated samples.

(Hordeum vulgare)

Low-pressure plasma (26 Pa); discharge current (40 mA); treatment time (4 min); pulse duration (150-200 ms).

Diffuse coplanar surface barrier

Soybean (Glycine max) discharge plasma; voltage $(20 \mathrm{kV})$; pressure $(101,325 \mathrm{~Pa})$; frequency $(14 \mathrm{kHz})$; power $(400 \mathrm{~W})$; gas $\left(\mathrm{Air}, \mathrm{O}_{2}\right.$, and $\mathrm{N}_{2}$ ); treatment time (30-120 s).

DBD plasma; voltage (0-25 kV);

Soybean

(Glycine max)

pressure $(101,325 \mathrm{~Pa})$; frequency

$(50 \mathrm{~Hz})$; feed gases $\left(\mathrm{N}_{2}\right.$ and $\left.\mathrm{O}_{2}\right)$; treatment time ( 2 and $3 \mathrm{~min}$ ).
All treatments (except $\mathrm{N}_{2}$ plasma for 90 and $120 \mathrm{~s}$ ) positively affected germination percentage. For $60-\mathrm{s}_{2}$ plasma treatment, seed germination increased up to $80 \%$ compared to control $(60 \%)$.

\section{3- and 2-min of $\mathrm{N}_{2}$ and $\mathrm{O}_{2}$ plasma treatment} resulted in 1.2-fold increment in total fresh weight than control. The full length of soybean plant increased to $4-10 \%$ after plasma treatment.

The improvement in the seed germination and seedling growth was obtained at $80-\mathrm{W}$ power. Shoot length, shoot dry weight, root length, and root dry weight increased by 13.77, 21.95, 21.42, and $27.51 \%$, respectively, after plasma treatment with respect to control.

(Glycine max)

-2N low-pressure plasma; $p$ frequency $(13.56 \mathrm{MHz})$.
Pine (Pinus sylvestris), black pine (Pinus nigra Arnold), and mountain pine (Pinus mugo Turra)
Diffuse coplanar surface barrier discharge plasma; voltage $(20 \mathrm{kV})$; pressure $(101,325 \mathrm{~Pa})$; frequency $(14 \mathrm{kHz})$; power $(400 \mathrm{~W})$; treatment time (1-60 s).

The highest $P$. sylvestris seed germinations of $16.7 \%$ after 3 -s treatment and 50.7 and $59.3 \%$ after 5-s treatment. In $P$. mugo seed germinations of 29.3 and $44.7 \%$ after 1 - and 5 -s exposure and $P$. nigra germination after 1-, 3-, and 5-s plasma treatment were $59.3,80.7$, and $86.0 \%$, respectively. There was no significant increase in germination rate and germination index in all tested pines, except germination rate in $P$. sylvestris on the 4 th day was $45.4 \%$ after $3 \mathrm{~s}$ $(p<0.05)$ and control $(17.7 \%)$.

The highest seed germination rate of the control was $75.81 \pm 1.47 \%$, and after 90 -s treatment with plasma, germination was $91.71 \pm 1.11 \%$. The extended exposure time $>120$ s resulted in a pressure $(\sim 53,328.9 \mathrm{~Pa})$; power $(\sim 45 \mathrm{~W})$; voltage $(5 \mathrm{kV})$; frequency $(5 \mathrm{kHz})$; gas

$\left(\mathrm{Ar}+\mathrm{O}_{2}\right)$; treated time $30-120 \mathrm{~s}$. declined germination rate.

Diffuse Coplanar Surface Barrier

Maize (Zea mays)
Discharge (DCSBD) plasma; frequency $(14 \mathrm{kHz})$; pressure $(101,325 \mathrm{~Pa})$; voltage $(10 \mathrm{kV})$; plasma density $\left(100 \mathrm{~W} . \mathrm{cm}^{-3}\right)$; gas (Air); treatment time (60 and $120 \mathrm{~s}$ ) 60-s treatment positively influenced germination and early growth of seedlings. The length, fresh and dry weight increased by $21 \%, 10 \%$, and $14 \%$, respectively, while increased plasma exposure for $120 \mathrm{~s}$ significantly showed inhibition for all parameters compared with control. 
Table 3. Cont.

\begin{tabular}{|c|c|c|c|}
\hline Plant Species & Plasma Device & Seed Germination & Ref. \\
\hline $\begin{array}{l}\text { Wheat } \\
\text { (Triticum spp.) }\end{array}$ & $\begin{array}{l}\text { Low-pressure plasma; He gas; pressure } \\
\text { (150 Pa); variable power }(60-100 \mathrm{~W}) \text {. }\end{array}$ & $\begin{array}{l}\text { The improved germination rate and germination } \\
\text { potential compared with control. }\end{array}$ & [89] \\
\hline $\begin{array}{c}\text { Wheat } \\
\text { (Triticum aestivum) }\end{array}$ & $\begin{array}{l}\text { Surface discharge plasma; voltage } \\
(15 \mathrm{kV}) \text {; pressure }(101,325 \mathrm{~Pa}) ; \\
\text { frequency (50 Hz); average power } \\
(2.7 \mathrm{~W}) ; \text { treatment time }(15 \mathrm{~min})\end{array}$ & Slightly affected the germination rate. & [90] \\
\hline $\begin{array}{c}\text { Wheat } \\
\text { (Triticum aestivum) }\end{array}$ & $\begin{array}{c}\text { Glow discharge plasma; pressure } \\
(\sim 1333.22 \mathrm{~Pa}) \text {; frequency }(3-5 \mathrm{kHz}) \text {; gas } \\
\left(\mathrm{Ar}+\mathrm{O}_{2}\right) \text {; treatment time }(60 \mathrm{~s})\end{array}$ & $\begin{array}{l}\text { Enhanced seed germination of } 12.38 \% \text { and } 7.14 \% \\
\text { were obtained for } \mathrm{Ar}+\mathrm{O}_{2} \text { gas mixture and Air, } \\
\text { respectively }\end{array}$ & [91] \\
\hline $\begin{array}{c}\text { Wheat } \\
\text { (Triticum aestivum) }\end{array}$ & $\begin{array}{c}\text { Atmospheric pressure dielectric barrier } \\
\text { discharge plasma; pressure }(101,325 \mathrm{~Pa}) ; \\
\text { frequency }(16 \mathrm{kHz}) \text {; voltage }(20 \mathrm{kV}) ; \\
\text { power }(30 \mathrm{~W}) ; \text { treatment time } \\
(10-900 \mathrm{~s}) .\end{array}$ & $\begin{array}{l}\text { Plasma treatment increased the germination } \\
\text { during the first } 48 \mathrm{~h} \text { after seeding, for short } \\
\text { treatment times }(<120 \mathrm{~s}) \text {. Germination } \\
\text { percentage up to } 40 \% \text { for } 120 \mathrm{~s} \text { compared to } \\
\text { control }(20 \%) \text {. }\end{array}$ & [92] \\
\hline $\begin{array}{l}\text { Wheat } \\
\text { (Triticum aestivum) }\end{array}$ & $\begin{array}{c}\text { Glow discharge plasma; pressure } \\
\text { (1333 Pa); frequency ( } 3-5 \mathrm{kHz}) \text {; feed gas } \\
\text { (mixture of } \mathrm{O}_{2} \text { and Air); treatment time } \\
(3-9 \mathrm{~min})\end{array}$ & $\begin{array}{l}\text { 6-min treatment resulted in } 95-100 \% \text { seed } \\
\text { germination and a } 20 \% \text { increase in wheat yield. }\end{array}$ & [93] \\
\hline $\begin{array}{c}\text { Wheat } \\
\text { (Triticum aestivum) }\end{array}$ & $\begin{array}{c}\text { Low-pressure Plasonic AR-550-M } \\
\text { plasma; pressure (140 Pa); power } \\
\text { (500 W); feed gas (Air); treatment time } \\
\text { (180-2400 s). }\end{array}$ & $\begin{array}{l}\text { Plasma treatment inhibited the germinating } \\
\text { acceleration of wheat in first days, but } \\
\text { enhancement of footstalk was observed on } \\
\text { plants grown from seeds treated for medium } \\
\text { time. 3-min treatment caused heavier shoots (dry } \\
\text { weight 5.4 g) than samples treated by 10-, 20-, } \\
\text { and 40-min plasma exposure. }\end{array}$ & [94] \\
\hline $\begin{array}{c}\text { Wheat } \\
\text { (Xiaoyan 22) }\end{array}$ & $\begin{array}{l}\text { Low-pressure dielectric barrier } \\
\text { discharge plasma; pressure }(1333 \mathrm{~Pa}) \text {; } \\
\text { voltage }(0-50 \mathrm{kV}) \text {; frequency }(50 \mathrm{~Hz}) ; \\
\left.\text { working gases (Air, } \mathrm{N}_{2}, \text { Ar, and } \mathrm{O}_{2}\right)\end{array}$ & $\begin{array}{c}\text { Increased germination potential to } 35.5,28 \text {, and } \\
24 \% \text { for } \mathrm{Ar}, \mathrm{N}_{2} \text {, and Air feed gases' } \\
\text { plasma, respectively. }\end{array}$ & [95] \\
\hline $\begin{array}{c}\text { Wheat } \\
\text { (Xiaoyan 22) }\end{array}$ & $\begin{array}{c}\text { Dielectric barrier discharge plasma; } \\
\text { pressure }(101,325 \mathrm{~Pa}) \text {; working gas } \\
\text { (Air); power }(1.50 \mathrm{~W}) \text {; voltage }(13.0 \mathrm{kV})\end{array}$ & $\begin{array}{l}\text { After treatment, the increased germination rate, } \\
\text { germination potential, and germination index } \\
\text { were } 9.1,26.7 \text {, and } 16.9 \% \text {, respectively. }\end{array}$ & [96] \\
\hline $\begin{array}{c}\text { Wheat } \\
\text { (Xiaoyan 22) }\end{array}$ & $\begin{array}{l}\text { DBD plasma; voltage }(13 \mathrm{kV}) \text {; pressure } \\
\text { (101,325 Pa); power }(1.50 \mathrm{~W}) \text {; feed gas } \\
\text { (Air); treatment time (7 min). }\end{array}$ & $\begin{array}{l}\text { The germination potential and germination rate } \\
\text { were increased to } 27.2 \text { and } 27.6 \% \text {, respectively, } \\
\text { after plasma treatment. Additionally, root and } \\
\text { shoot length increased after treatment. }\end{array}$ & [97] \\
\hline $\begin{array}{l}\text { Wheat } \\
\text { (Giza 168) }\end{array}$ & $\begin{array}{c}\text { Plasma jet; voltage }(2.6 \mathrm{kV}) \text {; pressure } \\
(101,325 \mathrm{~Pa}) \text {; current }(38.1 \mathrm{~mA}) \text {; feed gas } \\
\left(\mathrm{N}_{2}\right) \text {; treatment time }(4 \mathrm{~min})\end{array}$ & $\begin{array}{l}\text { Enhanced germination rate and germination } \\
\text { percentage were obtained after plasma treatment. } \\
\text { Plasma treatment for } 4 \text { min resulted in } 54.3 \% \\
\text { higher mean dry weight than control samples. }\end{array}$ & [98] \\
\hline Winter Wheat & $\begin{array}{l}\text { Dielectric barrier discharge plasma } \\
\text { reactor with coaxial geometry; working } \\
\text { gases He and Ar. }\end{array}$ & $\begin{array}{l}\text { He and Ar feed showed faster germination for } \\
\text { Ar plasma than He plasma and control }\end{array}$ & [99] \\
\hline Winter Wheat & $\begin{array}{l}\text { RF pressure plasma; frequency (13.56 } \\
\text { MHz); feed gas (Air); treatment time } \\
\text { (180 s). }\end{array}$ & $\begin{array}{l}\text { After plasma treatment, the grain and spike } \\
\text { yields were enhanced to } 58 \text { and } 75 \% \text {, } \\
\text { respectively, compared to control in the presence } \\
\text { of haze stress. }\end{array}$ & [100] \\
\hline $\begin{array}{c}\text { Pea } \\
\text { (Pisum sativum) }\end{array}$ & $\begin{array}{l}\text { Dielectric surface barrier discharge } \\
\text { plasma; pressure }(101,325 \mathrm{~Pa}) ; \\
\text { frequency }(14 \mathrm{kHz}) ; \text { voltage }(10 \mathrm{kV}) ; \\
\text { average power density }\left(2.3 \mathrm{~W} / \mathrm{cm}^{2}\right) ; \\
\text { treatment time }(60-300 \mathrm{~s}) .\end{array}$ & $\begin{array}{c}\text { Significant increase in the total percentage of } \\
\text { seed germination to } 95 \% \text { after } 120 \text {-s treatment, } \\
\text { while } 77.5 \% \text { for control. }\end{array}$ & [101] \\
\hline
\end{tabular}


Table 3. Cont.

\begin{tabular}{|c|c|}
\hline Plant Species & Plasma Device \\
\hline $\begin{array}{c}\text { Pea } \\
\text { (Pisum sativum) }\end{array}$ & $\begin{array}{l}\text { FSG plasma (a semi-automatic device) } \\
\text { system; voltage }(15 \mathrm{kV}) ; \text { gas (Air); } \\
\text { treatment time (30 s and } 60 \mathrm{~s}) .\end{array}$ \\
\hline $\begin{array}{c}\text { Pea } \\
(\text { Pisum satioum })\end{array}$ & $\begin{array}{c}\text { Diffuse coplanar surface barrier } \\
\text { discharge; voltage }(20 \mathrm{kV}) \text {; frequency } \\
(14 \mathrm{kHz}) \text {; power }(400 \mathrm{~W}) \text {; gas }\left(\mathrm{N}_{2}, \mathrm{O}_{2}\right. \\
\left.\text { and mixture of } \mathrm{N}_{2}: \mathrm{O}_{2}\right) \text {; treatment time } \\
(60-300 \mathrm{~s}) .\end{array}$ \\
\hline $\begin{array}{l}\text { Mung bean } \\
\text { (Vigna radiata) }\end{array}$ & $\begin{array}{c}\text { Microplasma array plasma; pressure } \\
(101,325 \mathrm{~Pa}) \text {; frequency }(9.0 \mathrm{kHz}) \text {; gases } \\
\left(\text { Air, } \mathrm{O}_{2}, \mathrm{~N}_{2} \text {, and } \mathrm{He}\right) ; \text { treatment time } \\
\text { (10 min). }\end{array}$ \\
\hline Ajwain & $\begin{array}{c}\text { RF capacitively coupled plasma; } \\
\text { frequency }(13.56 \mathrm{MHz}) \text {; pressure } \\
\text { (9.9 Pa); power (50-100 W); treatment } \\
\text { time (2 min). }\end{array}$ \\
\hline
\end{tabular}

Poppy Plasonic AR-550-M; power $(500 \mathrm{~W})$;

(Papaver somniferum) low-pressure; gas (mixture of $\mathrm{O}_{2}$ and

Ar); treatment time (0-5400 s).
Sweet basil (Ocimum basilicum)
RF plasma; frequency (13.56 MHz); frequency; power $(30-270 \mathrm{~W})$; pressure (40 Pa); treatment time (10 $\mathrm{min})$; gas (mixture of $\mathrm{O}_{2}$ and $\mathrm{Ar}$ ).
$80 \%$ and $74 \%$ of seeds were germinated after $30-\mathrm{s}$ and 60 -s treatment, respectively.

The least seed DNA was damaged in the presence of Air plasma; however, DNA damage increased with increasing the $\mathrm{N}_{2}$ content and treatment time. The improved germination and growth were observed for 120-s treatment, and air plasma showed improved germination with the least DNA damage.

The germination index increased by 58.3 and $41.7 \%$ for Air and $\mathrm{O}_{2}$ treatments, respectively. $\mathrm{He}$ or $\mathrm{N}_{2}$ plasma resulted in no notable disparity than control.

The germination percentage increased by $11.1 \%$ at $50-\mathrm{W}$ power, although higher RF plasma power damaged the seeds.

Major differences in seed germination rate were recorded for 3-min, 5-min, and 10-min plasma treatment than vacuum and reference samples. Short treatment time showed significantly higher seedling growth on the 6th day of cultivation for short treatment time. The treated samples were $137 \%, 125 \%$, and $131 \%$ longer for $3 \mathrm{~min}, 5 \mathrm{~min}$, and $10 \mathrm{~min}$, respectively, than reference samples.

Under drought stress, germination was improved by $6.25 \%$ and $4.44 \%$ for Zhongshuang 7 and Zhongshuang 11, respectively. Seedling growth characteristics such as root and shoot lengths, lateral root number, and dry weight were improved significantly after plasma treatment. Plasma treatment increased the superoxide dismutase activity by $17.71 \%$ and $13.00 \%$ for Zhongshuang 7 and 11, respectively. Catalase activity increased by $16.52 \%$ and $13.21 \%$ for Zhongshuang 7 and 11, respectively. An increase in soluble sugar and protein contents but a decrease in the malondialdehyde content for the plasma-treated samples occurred.
The 150-W plasma treatment had the highest stimulatory effect on germination and vigor among all the studied doses of treatments.
Ref.

[102]

Air-DBD for 120-s treatment increased the seed germination rate by $14 \pm 0.6 \%$ than control. The maximum root and shoot length and dry weight were also observed for the same treatment time. Air-DBD treatment enhanced the nitrogen content in the seeds that contributed to an enhanced germination rate. Plasma-treated seed revealed the enhanced superoxide dismutase and Ascorbate peroxidases' (APXs') activities.
Dielectric surface barrier discharge

Black gram

(Vigna mungo) plasma; pressure (53,328 $\mathrm{Pa})$; power $(45$ $\mathrm{W})$; voltage $(5 \mathrm{kV})$; frequency $(4.5 \mathrm{kHz})$; gas (Air); treatment time (20-180 s). 
Recently, heat-stressed Rice (Oryza sativa) seeds treated with Air-scalar DBD plasma with 2.17-W discharge power showed a higher germination rate than without plasma heatstressed seeds throughout the germination time course [65]. Rice seeds with low-pressure ( 1333 Pa) DBD plasma working with Ar + Air gas mixture [66], hybrid cold plasma (HCP) with Ar feed gas [67], and Air-atmospheric pressure multi-pin plasma generator [68] showed an increase in seed germination and germination rate. The percentage increase in seed germination and germination rate depends on the plasma device and treatment time and it is independent of the pressure (positive effect shown in low-pressure and atmospheric pressure).

In plasma agriculture, another most-studied plant species was radish (Raphanus sativus). Radish treated with Air-scalar DBD [70], Ar-plasma jet [74], and Air-radiofrequency (RF) low-pressure (40 Pa) plasma [76] showed a positive effect in the seed germination. Our recent work reported that an increase in maximal germination percentage depends upon the harvest year and seed coat color [70]. The maximal germination percentage increased by $8 \%$ for gray-color seeds for the 2017 harvest while not influencing the brown seeds. The plasma effect had no significant effect on seed germination for the 2018 harvest for brown and gray radish seeds [70]. This might be the reason that, in other studies, growth enhancement was reported after the various plasma treatment (scalar DBD, plasma torch, and RF-low pressure (100 Pa plasma) with $\mathrm{O}_{2}$ and $\mathrm{N}_{2}$ feed gases) but not the germination rate or percentage [71-73,75]. RF-low pressure (100 $\mathrm{Pa}$ ) plasma with $\mathrm{O}_{2}$ feed gas showed increased sprouts' length, but no change was observed on seed germination [75], while RF-low pressure (40 Pa) plasma with Air feed gas showed increased seed germination rate and growth enhancement [76]. Some authors reported that radish seeds treated with $\mathrm{O}_{2}$ - RF-low pressure $(100 \mathrm{~Pa})$ plasma showed no morphological changes on seed coat using SEM analysis and no oxides were formed (seed surface not modified) by FTIR-ATR spectra [75], while no surface analysis was performed using Air- RF-low pressure (40 Pa) plasma [76]. There might be seed surface modification that occurred at $40 \mathrm{~Pa}$, or, as we discussed above, the harvest year and seed coat color also play an essential role in the germination of radish sprouts.

Barley (Hordeum vulgare) seeds' treatment with microwave-driven Air plasma showed a negative effect on maximum germination [79], while barley seeds treated with lowpressure (26 Pa) plasma had no effect on the germination [81], whereas treatment with surface dielectric barrier discharge (SDBD) plasma resulted in the early growth of barley sprouts [80]. The increase in early growth and fresh weight of barley sprouts was due to improved levels of the primary metabolites (soluble sugars and free amino acids) and secondary metabolites (saponarin, GABA, and policosanols) [80]. Soybean (Glycine max) seeds treated with $\mathrm{O}_{2}$-diffuse coplanar surface barrier discharge (DCSBD) plasma [82] and HD-2N low-pressure (150 Pa) plasma [84] resulted in a positive effect on seed germination. The reduced germination of control soybean seeds was due to seeds' age. The increased germination after DCSBD was due to a positive impact on succinate dehydrogenase activity, while inhibition of germination at high DCSBD doses caused by significant oxidative stress resulted in lipid peroxidation, stimulated lactate, and alcohol dehydrogenase activities and inhibited succinate dehydrogenase activity [82]. Maize seeds (Zea mays) treated with low-frequency glow discharge plasma (LFGD) at $~ 53,328.9$ Pa [86] and Air-DCSBD caused a positive influence in germination [87]. LFGD treatment enhances enzymatic activities related to seed germination and stimulates the decomposition of the essential nutrients that trigger compounds to increase the consumption of seed reserves and promote seedling [86]. Dehydrogenase activity was significantly higher in embryos after the seed was treated with Air-DCSBD that might affect early germination [87].

We observed that wheat was the most studied plant species using NTP at low pressure and atmospheric pressure, and, in the majority of cases, it showed a positive impact on germination. Wheat (Triticum spp.) seeds treated with low-pressure plasma [88,89] revealed an improved germination rate and germination potential. Similarly, wheat (Triticum aestivum) seeds treated with surface discharge plasma [90], low-frequency glow discharge 
plasma at 1333 Pa [91,93], and atmospheric pressure DBD [92] showed increased germination percentage and germination rate, while low-pressure (140 Pa) Plasmonic AR-550-M plasma [94] demonstrated inhibited germination but enhanced footstalk. Wheat (Xiaoyan 22) seeds treated with DBD plasma working with various working gases showed an increase in germination rate and germination potential [95-97]. Additionally, wheat (Giza 168) [98] and winter wheat [99] seeds treated with plasma jet and DBD reactor also showed enhanced germination potential, respectively.

The impact of feed gases on the wheat germination was also reported, as the moderateintensity DBD plasma in the presence of Air, $\mathrm{N}_{2}$, and Ar plasmas showed positive impacts on the seed germination, while no significant effect was obtained for the $\mathrm{O}_{2}$ plasma treatment. This was because the etching effect was stronger for $\mathrm{Ar}$ and $\mathrm{N}_{2}$ plasma than $\mathrm{O}_{2}$ plasma. Additionally, the relative electroconductivity of wheat increased for Air, $\mathrm{N}_{2}$, and Ar plasmas that remained consistent with the change in water uptake and germination. Moreover, soluble protein production was also improved after plasma treatment; hence, plasma treatment can accelerate the physiological reactions that increase the germination index [95]. It was also mentioned that plasma treatment helps in penetrating active compounds, which further results in an accelerated wheat seed germination process [98]. $\mathrm{H}_{2} \mathrm{O}_{2}$ plays a key role in the plant life cycle, such as the release of dormancy during seed germination [110]. It was also reported that external $\mathrm{H}_{2} \mathrm{O}_{2}$ treatment helps in seed germination [111]. Thus, $\mathrm{H}_{2} \mathrm{O}_{2}$ is produced during the plasma discharge taken up by seeds during the imbibition process and regulates the metabolic processes that helps in germination [99].

Almost all the researchers found that NTP treatment assists the penetration of RONS to the seeds that benefit from increasing protein and antioxidant levels and accelerates the physiological reactions. During these processes, the reaction of RONS with proteins may have both positive and negative impacts on the plants. Additionally, NTP is used to deactivate enzymes in beverages such as fruit juices to maintain the quality of food products. To consider this, we focus on the NTP-induced modification in proteins' / enzymes' structures and functions in the next section.

\section{NTP Effect on the Structural and Functional Changes of Proteins/Enzymes at Atmospheric Pressure}

Like the PEF effect on proteins/enzymes, plasma treatment also modified the proteins' / enzymes' structure and function, as described in Table 4.

Table 4. Conformational and functional changes of proteins/enzymes after NTP treatment.

\begin{tabular}{|c|c|c|c|}
\hline Proteins/Enzymes & Treatment Condition & Results & Ref \\
\hline Lipase & $\begin{array}{l}\text { Radiofrequency glow discharge Jet; } \\
\text { power }(180 \mathrm{~W}) \text {; gas }(\mathrm{He}) \text {; temperature } \\
\left(\sim 57^{\circ} \mathrm{C}\right) .\end{array}$ & $\begin{array}{c}\text { The relative lipase activity was increased by } \\
1.4 \text { times after } 50 \text {-s treatment. The increase in } \\
\text { fluorescence emission intensity was compared } \\
\text { to control. }\end{array}$ & [112] \\
\hline Lysozyme & $\begin{array}{c}\text { Low-frequency plasma; gas } \\
\left(\mathrm{He}+\mathrm{O}_{2}\right) ; \text { voltage }(-3.5 \text { to }+5.0 \mathrm{kV}) \\
\text { frequency }(13.9 \mathrm{kHz})\end{array}$ & $\begin{array}{l}\text { This resulted in decreased residual activity after } \\
\text { the 30-min plasma treatment. Additionally, the } \\
\text { secondary structure of lysozyme changed slightly } \\
\text { after plasma exposure. The quenching in } \\
\text { fluorescence intensity was observed with } \\
\text { plasma treatment. }\end{array}$ & [113] \\
\hline Lysozyme & $\begin{array}{l}\text { Dielectric surface barrier discharge } \\
\text { plasma; voltage }(1.23 \mathrm{kV}) \text {; frequency } \\
\text { (16 kHz); gas }\left(\mathrm{N}_{2} \text { and Air). }\right. \\
\text { Plasma Jet; voltage }(0.6 \mathrm{kV}) ; \\
\text { frequency }(24 \mathrm{kHz}) 24 \mathrm{kHz} \text { frequency; } \\
\text { gas }\left(\mathrm{N}_{2} \text { and Air). }\right.\end{array}$ & $\begin{array}{c}\text { DBD and Jet for } 8 \text { and } 12 \text { min with Air and } \mathrm{N}_{2} \text { as } \\
\text { feed gases decreased activity. The structure of } \\
\text { lysozyme was more disturbed with } \mathrm{N}_{2} \text { feed gas } \\
\text { than Air feed gas plasma. }\end{array}$ & [114] \\
\hline
\end{tabular}


Table 4. Cont.

\begin{tabular}{|c|c|c|c|}
\hline Proteins/Enzymes & Treatment Condition & Results & Ref \\
\hline$\alpha$-Chymotrypsin & $\begin{array}{l}\text { Plasma Jet; power supply: Neon light } \\
\text { trans-operated at } 60 \mathrm{~Hz} \text {; treatment } \\
\text { time ( } 5 \mathrm{~min}) \text {; gas (Air). }\end{array}$ & $\begin{array}{l}\text { Decrease in thermodynamic properties of } \\
\alpha \text {-chymotrypsin after plasma treatment. } \\
\text { Additionally, there was an increase in } \alpha \text {-helix and } \\
\text { a reduction of } \beta \text {-sheet content and quenching in } \\
\text { fluorescence spectra after plasma treatment. }\end{array}$ & [115] \\
\hline $\begin{array}{l}\text { Hemoglobin and } \\
\text { Myoglobin }\end{array}$ & $\begin{array}{l}\text { Plasma Jet; power supply: Neon light } \\
\text { trans-operated at } 60 \mathrm{~Hz} \text {; gases (Air, } \\
\left.\mathrm{N}_{2} \text { and Ar); treatment time ( } 3 \mathrm{~min}\right)\end{array}$ & $\begin{array}{l}\text { The maximum decrease in } \alpha \text {-helix and the highest } \\
\text { level of protein oxidation for } \mathrm{N}_{2} \text { plasma than Air } \\
\text { and Ar feed gases' plasma. }\end{array}$ & [116] \\
\hline Hemoglobin & $\begin{array}{l}\text { Dielectric surface barrier discharge } \\
\text { plasma; frequency }(10 \mathrm{kHz}) \text {; voltage } \\
(9.2 \mathrm{kV}) \text {; current }(0.2 \mathrm{~A}) \text {; discharge } \\
\text { power density }\left(1.49 \mathrm{~W} / \mathrm{cm}^{2}\right) \text {; gases } \\
\left.\text { (Air, Ar, He, NO }(10 \%)+\mathrm{N}_{2} \text { and } \mathrm{N}_{2}\right) \text {; } \\
\text { treatment time }(10 \mathrm{~min}) .\end{array}$ & $\begin{array}{l}\text { The 10-min DBD treatment with } \mathrm{O}_{2}, \mathrm{~N}_{2} \text {, and Air } \\
\text { feed gases' plasma resulted in minor changes in } \\
\alpha \text {-helix and } \beta \text {-sheet content, while changes were } \\
\text { insignificant for Ar, He, and } \mathrm{NO}(10 \%)+\mathrm{N}_{2} \text { gases' } \\
\text { plasma. Fluorescence spectroscopy showed the } \\
\text { maximum redshift Air plasma compared to other } \\
\text { feed gases. }\end{array}$ & [117] \\
\hline $\begin{array}{l}\text { Hemoglobin and } \\
\text { Myoglobin }\end{array}$ & $\begin{array}{l}\text { DBD plasma Jet; voltage }(0.7 \mathrm{kV}) \\
\text { current }(3 \mathrm{~mA}) ; \text { frequency }(16 \mathrm{kHz}) \\
\text { gases }\left(\mathrm{Ar}, \mathrm{Ar}+\mathrm{O}_{2}(0.2 \%, 0.3 \% \text {, and }\right. \\
0.4 \%), \mathrm{Ar}+\mathrm{N}_{2}(0.2 \%, 0.3 \% \\
\text { and } 0.4 \%))\end{array}$ & $\begin{array}{l}\text { The CD and Fourier transform infrared } \\
\text { spectroscopy data showed as the treatment time } \\
\text { increased, the percentage of } \alpha \text {-helical decreased, } \\
\text { and the percentage of } \beta \text {-sheet increased for pure } \\
\text { Ar plasma and Ar mixtures }\left(\mathrm{Ar}+\mathrm{O}_{2} \text { and } \mathrm{Ar}+\mathrm{N}_{2}\right) \text {. }\end{array}$ & [118] \\
\hline $\begin{array}{c}\text { Alkaline } \\
\text { phosphatase }\end{array}$ & $\begin{array}{l}\text { Dielectric surface barrier discharge } \\
\text { plasma; gas (Air); voltage (40-60 kV); } \\
\text { operation time (15-300 s). }\end{array}$ & $\begin{array}{l}\text { The decreased } \alpha \text {-helix and } \beta \text {-sheets' content as } \\
\text { plasma treatment time increased. The reduced } \\
\text { activity of alkaline phosphatase was obtained after } \\
\text { the } 180 \text {-s treatment. }\end{array}$ & [119] \\
\hline MTH1880 & $\begin{array}{l}\text { Dielectric surface barrier discharge } \\
\text { plasma; gas (Air); voltage }(0.9 \mathrm{kV}) \\
\text { treatment time (10-20 min). }\end{array}$ & $\begin{array}{l}\text { The decrease and increase in } \alpha \text {-helix and } \beta \text {-sheets' } \\
\text { contents, respectively, after plasma treatment. The } \\
\text { quenching in fluorescence spectra increased with } \\
\text { treatment time due to changes in the Tyrosine } \\
\text { residue environment or its modification. The } \\
\text { melting temperature of MTH was not significantly } \\
\text { changed after plasma treatment for } 10 \text { and } 15 \text { min, } \\
\text { whereas it dropped by } 5{ }^{\circ} \mathrm{C} \text { for } 20 \text {-min treatment. } \\
{ }^{1} \mathrm{H}-15 \mathrm{~N} \text { NMR spectroscopy showed peak shifts for } \\
\text { Histidine } 52 \text { and Tyrosine } 59 \text { after } 20 \text {-min } \\
\text { plasma treatment. }\end{array}$ & [120] \\
\hline $\begin{array}{c}\text { Lactate } \\
\text { dehydrogenase }\end{array}$ & $\begin{array}{l}\text { Dielectric surface barrier discharge } \\
\text { plasma; gas }(\mathrm{He}) \text {; voltage }(12 \mathrm{kV}) ; \\
\text { frequency }(24 \mathrm{kHz}) \text {; power density } \\
\qquad\left(0.9 \mathrm{~W} / \mathrm{cm}^{2}\right)\end{array}$ & $\begin{array}{l}\text { The } \alpha \text {-helix content decreased, whereas } \beta \text {-sheet } \\
\text { content increased by direct plasma treatment. } \\
\text { Indirect plasma treatment caused decreased } \\
\alpha \text {-helix content, and } \beta \text {-sheet content increased. } \\
\text { The activity was reduced to } 67.5 \% \text { after direct } \\
\text { plasma exposure and } 71.14 \% \text { after the indirect } \\
\text { plasma treatment for } 300 \mathrm{~s} \text {. }\end{array}$ & [121] \\
\hline $\begin{array}{l}\text { NADPH oxidases } 1 \\
\text { (NOX1) }\end{array}$ & $\begin{array}{l}\text { Dielectric surface barrier discharge } \\
\text { plasma; gas (Air); voltage }(1.08 \mathrm{kV}) \\
\text { treatment time }(1-5 \mathrm{~min}) . \\
\text { Plasma Jet; gas (Air); voltage }(1.6 \mathrm{kV}) ; \\
\text { treatment time (1-3 min). }\end{array}$ & $\begin{array}{l}{ }^{1} \mathrm{H}^{15} \mathrm{~N} \text { NMR spectroscopy showed the peak shifts } \\
\text { for glutamine } 413 \text {, aspartic acid } 427 \text {, cysteine } 430 \\
\text { and } 441 \text {, valine } 432 \text {, glycine } 443 \text { and } 446 \text {, and } \\
\text { arginine } 444 \text { after plasma treatment. }\end{array}$ & [122] \\
\hline Tyrosinase & $\begin{array}{l}\text { Dielectric surface barrier discharge } \\
\text { plasma; gas }\left(\mathrm{He} \text { and } \mathrm{He}+\mathrm{O}_{2}\right) \\
\text { voltage }\left(0.85 \text { or } 1.1 \mathrm{kV}_{\mathrm{rms}}\right) \text {; frequency } \\
\text { (20 kHz); treatment time (10-60 min). }\end{array}$ & $\begin{array}{l}\text { Tyrosinase enzyme treated with plasma with } \mathrm{He} \\
\text { and } \mathrm{He}+\mathrm{O}_{2} \text { feed gases showed decreased activity. } \\
\text { The activity was significantly reduced after } \mathrm{He}+ \\
\mathrm{O}_{2} \text { plasma treatment than pure He plasma after } \\
30 \text { min. }\end{array}$ & [123] \\
\hline
\end{tabular}


Table 4. Cont.

\begin{tabular}{|c|c|c|c|}
\hline Proteins/Enzymes & Treatment Condition & Results & Ref \\
\hline $\begin{array}{l}\text { Peroxidase (POD) and } \\
\text { Polyphenol oxidase } \\
\text { (PPO) }\end{array}$ & $\begin{array}{c}\text { Plasma Jet; voltage }(2-6 \mathrm{kV}) \\
\text { frequency }(1.1 \mathrm{MHz}) \text {; gas }(\mathrm{Ar} \text { and } \\
\left.\mathrm{Ar}+\mathrm{O}_{2}(0.01-0.1 \%)\right) \text {; treatment time } \\
(0-360 \mathrm{~s})\end{array}$ & $\begin{array}{l}\text { The combination of } \mathrm{Ar}+0.05 \% \mathrm{O}_{2} \text { plasma for } \\
350 \mathrm{~s} \text { resulted in } 90 \% \text { inactivated polyphenol } \\
\text { oxidase. At the same time, } \mathrm{Ar}+0.05 \% \mathrm{O}_{2} \text { resulted } \\
\text { in an } 85 \% \text { decrease in the peroxidase activity. For } \\
\text { polyphenol oxidase and peroxidase, the } \alpha \text {-helix } \\
\text { content decreased, while } \beta \text {-sheet content increased } \\
\text { after plasma treatment. }\end{array}$ & [124] \\
\hline $\begin{array}{l}\text { Horseradish } \\
\text { Peroxidase }\end{array}$ & $\begin{array}{c}\text { Dielectric surface barrier discharge } \\
\text { plasma Jet; gas }\left(\mathrm{Ar}+\mathrm{O}_{2}\right) \text {; voltage } \\
(7 \mathrm{kV}) .\end{array}$ & $\begin{array}{l}\text { Peroxidase activity decreased to } 17 \% \text { after } 10-\mathrm{min} \\
\text { plasma treatment. Moreover, the } \alpha \text {-helix content } \\
\text { decreased and } \beta \text {-sheet increased after } 10-\text { min } \\
\text { plasma exposure, and no remarkable change was } \\
\text { observed for the random coil. }\end{array}$ & [125] \\
\hline $\begin{array}{l}\text { Peroxidase in } \\
\text { tomato extract }\end{array}$ & $\begin{array}{l}\text { Dielectric surface barrier discharge } \\
\text { plasma; gas (He and Ar); voltage }(10 \mathrm{kV}) \text {; } \\
\text { power (20 W); operation time (1-6 min). } \\
\text { Gliding Arc; gas (Air); voltage } \\
(14 \mathrm{kV}) \text {; frequency }(20 \mathrm{kHz}) \text {; power } \\
\text { (50 W). }\end{array}$ & $\begin{array}{l}\text { The decrease in peroxidase activity to } 7.32 \% \text { after } \\
\text { plasma treatment. }\end{array}$ & [126] \\
\hline $\begin{array}{l}\text { Pectin } \\
\text { Methylesterase, } \\
\text { lipoxygenase, } \\
\text { Polyphenol Oxidase, } \\
\text { and Peroxidase in } \\
\text { carrot juice }\end{array}$ & $\begin{array}{l}\text { Dielectric surface barrier discharge } \\
\text { plasma; gas (Air); voltage }(60-80 \mathrm{kV}) \text {; } \\
\text { operation time (4 min). }\end{array}$ & $\begin{array}{l}\text { The minimum residual activities of } \\
\text { pectin-methylesterase after plasma treatment. The } \\
\text { residual activity, lipoxygenase, polyphenol } \\
\text { oxidase, and peroxidase were } 10.21,13.42,11.20 \text {, } \\
\text { and } 15.73 \% \text { observed, respectively, at } 70 \mathrm{kV} \text { for } \\
\text { 4-min treatment. }\end{array}$ & [127] \\
\hline $\begin{array}{c}\alpha \text {-amylase } \\
\text { (dry brown rice) }\end{array}$ & $\begin{array}{l}\text { Dielectric surface barrier discharge } \\
\text { plasma; power }(250 \mathrm{~W}) \text {; frequency } \\
(15 \mathrm{kHz}) \text {; treatment time }(5-20 \mathrm{~min}) \text {. }\end{array}$ & $\begin{array}{l}\text { The } \alpha \text {-amylase activity significantly increased after } \\
\text { plasma treatment and the maximum increase after } \\
5 \text {-min treatment of around } 1.21 \text {-fold growth than } \\
\text { the control. }\end{array}$ & {$[128]$} \\
\hline
\end{tabular}

The lysozyme treated with a low-frequency (LF) plasma jet using $\mathrm{He}+\mathrm{O}_{2}$ feed gas decreases the residual activity and alters the secondary structure. After 30 min of plasma treatment, the lysozyme's random coil structure formed was nearly the same as that treated with 6.0 M guanidine $\mathrm{HCl}$. Quenching was observed without change in maximum wavelength in fluorescence spectra, and this was due to the chemical modification of tryptophan by NTP treatment. Some authors suggested that the change in lysozyme structure was due to reactive species such as $\cdot \mathrm{OH}, \mathrm{O}_{2}{ }^{-} \cdot \mathrm{HO}_{2} \cdot$, and $\mathrm{NO}$. that cause modification in the side chain of the amino acids such as tryptophan, tyrosine, cysteine, and phenylalanine [113]. In another study, the lysozyme was treated with DBD and Jet for $8 \mathrm{~min}, 12 \mathrm{~min}$ with Air and $\mathrm{N}_{2}$ as feed gases, resulting in decreased activity and structural changes. Circular dichroism (CD), fluorescence, and thermodynamic analysis revealed that the structure of lysozyme is more disturbed with $\mathrm{N}_{2}$ feed gas plasma than Air feed gas plasma. X-crystallographic data of lysozyme after NTP treatment showed that structural changes occurred at loop 3 and loop 6 along with the substrate-binding sites Tryptophan 62 and 108 and Aspartic acid 101.

Additionally, similar to the above work, the authors observed quenching in the fluorescence intensity without changing the wavelength after the plasma treatment. More structural and functional changes were observed in $\mathrm{N}_{2}$ plasma than Air plasma because $\mathrm{N}_{2}$ plasma generates more $\cdot \mathrm{OH}$ and $\mathrm{H}_{2} \mathrm{O}_{2}$ than Air plasma. The $\mathrm{N}_{2}$ metastable level $\left(\mathrm{N}_{2}\left(\mathrm{~A}_{3} \Sigma \mathrm{u}^{+}\right)\right.$) can dissociate $\mathrm{H}_{2} \mathrm{O}$ to produce $\cdot \mathrm{OH}$ and $\cdot \mathrm{H}$. In addition, the exciting $2 \mathrm{~N}$ atom also generates two $\mathrm{OH}$ radicals, while the presence of $\mathrm{O}_{2}$ in Air plasma reduced the $\mathrm{OH}$ density, affecting the $\mathrm{H}_{2} \mathrm{O}_{2}$ concentration [114]. Both studies showed that, independent of the plasma devices and feed gases, the decrease in residual activity and a change in the secondary structure was observed; no wavelength shift in the fluorescence spectra was noticed, while the quenching of the peak was observed in both studies [113,114]. Moreover, both 
studies concluded that the structural changes and functional changes in lysozyme were due to RONS generated by plasma, especially $\mathrm{OH}$ radical $[113,114]$, rather than plasma-induced UV [113].

Peroxidase and polyphenol oxidase treated with $\mathrm{Ar}+\mathrm{O}_{2}$ gas mixtures' plasma Jet caused structural and functional changes. The $\alpha$-helix content decreased, and $\beta$-sheet content increased after plasma treatment for both peroxidase and polyphenol oxidase proteins. In comparison, activity was reduced to $85 \%$ for peroxidase and $90 \%$ for polyphenol oxidase after plasma treatment [124]. In a separate study, horseradish peroxidase enzyme treated with $\mathrm{Ar}+\mathrm{O}_{2}$ DBD Jet decreased to $17 \%$ after a 10-min plasma treatment. Structural changes were similar to the above study in that the $\alpha$-helix content decreased and $\beta$-sheet increased [125]. Peroxidase tomato extract treated with He and Ar DBD plasma and Air gliding arc results in deceased peroxidase activity to $7.32 \%$ after plasma treatment [126]. Further, the residual activity of peroxidase and polyphenol oxidase in carrot juice treated with Air DBD plasma reduced to 15.73 and $11.20 \%$, respectively [127]. These studies showed that peroxidase and polyphenol oxidase activity could be reduced after the NTP treatment, independent of plasma sources and feeding gases. Although peroxidase showed more resistance to NTP treatment than polyphenol oxidase in all the cases, the structural changes were similar for peroxidase and polyphenol oxidase ( $\alpha$-helix content decreased and $\beta$-sheet increased).

\section{Conclusions}

PEF and NTP have great potential in agriculture (improved seed germination, seedling growth, high yield, and stress tolerance) and food processing (inactivation of enzymes in beverages such as fruit juices). Both technologies are environmentally friendly and easy to use. Understanding the mechanism behind improved seed germination after PEF and NTP treatments, on the other hand, is critical for future technological investigation and standardization. Different degrees of electric field strength were employed on different plant seeds in these studies, making it difficult to determine the particular electric field intensity that promotes seed germination. Nonetheless, we inferred from the research that moderate PEF intensity causes seed coat degradation, which increases water imbibition and allows an embryo to stretch, which aids seed germination. In contrast, seeds treated with a high intensity of PEF results in delayed seed germination that might damage the embryo, resulting in decreased seedling emergence. Therefore, it is important to use the same electric field intensity on different plant seeds under controlled atmospheric conditions to standardize the PEF treatment that helps in promoting germination. One of the mechanisms behind the PEF treatment is the modification of biomolecule structures (secondary and tertiary) and functional properties. It was noticed that PEF-induced structural changes also alter the physicochemical and functional properties of proteins/enzymes. In general, a decrease in the $\alpha$-helix content and an increase in the $\beta$-sheet were observed after moderate PEF treatment, while high-intensity PEF treatment caused aggregation. Furthermore, after PEF treatment, enzyme activity dropped, which was substantially influenced by treatment time, enzyme native structure, PEF intensity, and preheating temperature. However, more research at consistent NTP treatment circumstances and with numerous plant seed types is still needed. According to the investigations, there is no universal rule that assists seed germination in terms of pressure, power density, working gas composition, or treatment time. Furthermore, there was no clear answer to whether NTP enhanced physiological reactions by modifying the seed surface or not. In the maximum studies, no significant change in the morphology of the seed coat was reported. However, it was known that reactive species (RONS) and UV/VUS generated by NTP initiate the reactions in seeds despite the fact that PEF induced seed coat damage that helped in nutrients' uptake.

$\mathrm{NTP}^{\prime}$ s role in preserving fruit juices by deactivating enzymes and proteins showed both an increase and decrease in activity depending upon the treatment time and NTP source. Like PEF, the reduction in the $\alpha$-helix content and increase in $\beta$-sheet were observed in most cases after NTP treatment. Additionally, it was clearly shown in the NTP 
treatment the reactive species produced by NTP oxidized the amino acids of the proteins. Indeed, the oxidation of amino acids depends upon the treatment conditions, reactive species' concentration, and the oxidative property of amino acids (some are more prone to oxidation).

The overall result is that PEF and NTP treatment aid seed germination and seedling growth but also alter the structure and function of proteins and enzymes. Additionally, there is a need to develop the standard protocol using PEF or NTP parameters, treatment time, various plant seeds, seed coat color, harvest year, seed morphology, feeding gases composition, etc. to use these technologies at an industrial scale.

Author Contributions: Writing—original draft preparation, P.A.; writing—review and editing, T.O., K.K., M.S., D.W., K.T. (Katsuyuki Takahashi) and K.T. (Koichi Takaki). All authors have read and agreed to the published version of the manuscript.

Funding: This work was supported by JSPS-KAKENHI grant numbers JP20K14454, JP16H03895, JP19H05611, JP19H05462, JP19K14700, JP20H01893, and JP21H04451; JSPS: Core-to-Core Program JPJSCCA2019002; MEXT: function enhancement expenses; Plasma Bio Consortium, The Center for Low-temperature Plasma Sciences, Nagoya University.

Institutional Review Board Statement: Not applicable.

Informed Consent Statement: Not applicable.

Data Availability Statement: Not applicable.

Acknowledgments: All authors contributed to the planning and writing of the paper.

Conflicts of Interest: The authors declare no conflict of interest.

\section{References}

1. Scott, B.I.H. Electric Fields in Plants. Annu. Rev. Plant Physiol. 1967, 18, 409-418. [CrossRef]

2. Bertholon, N. De L'Électricité Des Végétaux (etc.)—Nicolas Bertholon—Google Books. Available online: https://books.google.co. jp/books?hl=en\&lr=\&id=1fRbAAAAcAAJ\&oi=fnd\&pg=PA127\&ots=1OzvJpuL4B\&sig=Um-a3mggcoQqhd_1ozpPp0vQ_gs\& redir_esc $=\mathrm{y} \# \mathrm{v}=$ onepage $\& \mathrm{q} \& \mathrm{f}=$ false $($ accessed on 16 November 2021).

3. Kotaka, S.; Krueger, A.P.; Andriese, P.C.; Nishizawa, K.; Ohuchi, T.; Takenobu, M.; Kozure, Y. Air ion effects on the oxygen consumption of barley seedlings. Nature 1965, 208, 1112-1113. [CrossRef] [PubMed]

4. Song, M.J.; Kang, T.H.; Han, C.S.; Oh, M.M. Air anions enhance lettuce growth in plant factories. Hortic. Environ. Biotechnol. 2014, 55, 293-298. [CrossRef]

5. Lee, S.R.; Kang, T.H.; Han, C.S.; Oh, M.M. Air anions improve growth and mineral content of kale in plant factories. Hortic. Environ. Biotechnol. 2015, 56, 462-471. [CrossRef]

6. Roberts, E.H. SEEDS. PHYSIOLOGY OF DEVELOPMENT AND GERMINATION (Book). Plant Cell Environ. 1986, 9, 356.

7. Attri, P.; Ishikawa, K.; Okumura, T.; Koga, K.; Shiratani, M. Plasma Agriculture from Laboratory to Farm: A Review. Processes 2020, 8, 1002. [CrossRef]

8. Vanga, S.K.; Singh, A.; Raghavan, V. Review of conventional and novel food processing methods on food allergens. Crit. Rev. Food Sci. Nutr. 2017, 57, 2077-2094. [CrossRef] [PubMed]

9. van Boekel, M.; Fogliano, V.; Pellegrini, N.; Stanton, C.; Scholz, G.; Lalljie, S.; Somoza, V.; Knorr, D.; Jasti, P.R.; Eisenbrand, G. A review on the beneficial aspects of food processing. Mol. Nutr. Food Res. 2010, 54, 1215-1247. [CrossRef]

10. Wang, Q.; Li, Y.; Sun, D.W.; Zhu, Z. Enhancing Food Processing by Pulsed and High Voltage Electric Fields: Principles and Applications. Crit. Rev. Food Sci. Nutr. 2018, 58, 2285-2298. [CrossRef]

11. Elez-Martínez, P.; Odriozola-Serrano, I.; Oms-Oliu, G.; Soliva-Fortuny, R.; Martín-Belloso, O. Effects of Pulsed Electric Fields Processing Strategies on Health-Related Compounds of Plant-Based Foods. Food Eng. Rev. 2017, 9, 213-225. [CrossRef]

12. Jacobo-Velázquez, D.A.; del Rosario Cuéllar-Villarreal, M.; Welti-Chanes, J.; Cisneros-Zevallos, L.; Ramos-Parra, P.A.; HernándezBrenes, C. Nonthermal processing technologies as elicitors to induce the biosynthesis and accumulation of nutraceuticals in plant foods. Trends Food Sci. Technol. 2017, 60, 80-87. [CrossRef]

13. Soliva-Fortuny, R.; Balasa, A.; Knorr, D.; Martín-Belloso, O. Effects of pulsed electric fields on bioactive compounds in foods: A review. Trends Food Sci. Technol. 2009, 20, 544-556. [CrossRef]

14. Barba, F.J.; Parniakov, O.; Pereira, S.A.; Wiktor, A.; Grimi, N.; Boussetta, N.; Saraiva, J.A.; Raso, J.; Martin-Belloso, O.; WitrowaRajchert, D.; et al. Current applications and new opportunities for the use of pulsed electric fields in food science and industry. Food Res. Int. 2015, 77, 773-798. [CrossRef]

15. Morales-de la Peña, M.; Rábago-Panduro, L.M.; Soliva-Fortuny, R.; Martín-Belloso, O.; Welti-Chanes, J. Pulsed Electric Fields Technology for Healthy Food Products. Food Eng. Rev. 2021, 13, 509-523. [CrossRef] 
16. Lee, S.; Oh, M.M. Electric stimulation promotes growth, mineral uptake, and antioxidant accumulation in kale (Brassica oleracea var. acephala). Bioelectrochemistry 2021, 138, 107727. [CrossRef] [PubMed]

17. Ohshima, T.; Tanino, T.; Guionet, A.; Takahashi, K.; Takaki, K. Mechanism of pulsed electric field enzyme activity change and pulsed discharge permeabilization of agricultural products. Jpn. J. Appl. Phys. 2021, 60, 060501. [CrossRef]

18. Takahashi, K.; Kawamura, S.; Takada, R.; Takaki, K.; Satta, N.; Fujio, T. Influence of a plasma-treated nutrient solution containing 2,4-dichlorobenzoic acid on the growth of cucumber in a hydroponic system. J. Appl. Phys. 2021, 129, 143301. [CrossRef]

19. Oey, I.; Roohinejad, S.; Leong, S.Y.; Faridnia, F.; Lee, P.Y.; Kethireddy, V. Pulsed electric field processing: Its technological opportunities and consumer perception. In Food Processing Technologies: Impact on Product Attributes; CRC Press: Boca Raton, FL, USA, 2016; pp. 447-516, ISBN 9781482257557.

20. Takaki, K.; Takahashi, K.; Guionet, A.; Ohshima, T. Pulsed power applications for protein conformational change and the permeabilization of agricultural products. Molecules 2021, 26, 6288. [CrossRef]

21. Ranjha, M.M.A.N.; Kanwal, R.; Shafique, B.; Arshad, R.N.; Irfan, S.; Kieliszek, M.; Kowalczewski, P.Ł.; Irfan, M.; Khalid, M.Z.; Roobab, U.; et al. A critical review on pulsed electric field: A novel technology for the extraction of phytoconstituents. Molecules 2021, 26, 4893. [CrossRef]

22. Gabrić, D.; Barba, F.; Roohinejad, S.; Gharibzahedi, S.M.T.; Radojčin, M.; Putnik, P.; Bursać Kovačević, D. Pulsed electric fields as an alternative to thermal processing for preservation of nutritive and physicochemical properties of beverages: A review. J. Food Process Eng. 2018, 41, 1-14. [CrossRef]

23. Attri, P.; Kim, Y.H.; Park, D.H.; Park, J.H.; Hong, Y.J.; Uhm, H.S.; Kim, K.N.; Fridman, A.; Choi, E.H. Generation mechanism of hydroxyl radical species and its lifetime prediction during the plasma-initiated ultraviolet (UV) photolysis. Sci. Rep. 2015, 5, 9332. [CrossRef]

24. Attri, P.; Koga, K.; Okumura, T.; Shiratani, M. Impact of atmospheric pressure plasma treated seeds on germination, morphology, gene expression and biochemical responses. Jpn. J. Appl. Phys. 2021, 60, 040502. [CrossRef]

25. Starič, P.; Vogel-Mikuš, K.; Mozetič, M.; Junkar, I. Effects of Nonthermal Plasma on Morphology, Genetics and Physiology of Seeds: A Review. Plants 2020, 9, 1736. [CrossRef] [PubMed]

26. Attri, P.; Koga, K.; Okumura, T.; Takeuchi, N.; Shiratani, M. Green route for ammonium nitrate synthesis: Fertilizer for plant growth enhancement. RSC Adv. 2021, 11, 28521-28529. [CrossRef]

27. Hoon Park, J.; Kumar, N.; Hoon Park, D.; Yusupov, M.; Neyts, E.C.; Verlackt, C.C.W.; Bogaerts, A.; Ho Kang, M.; Sup Uhm, H.; Ha Choi, E.; et al. A comparative study for the inactivation of multidrug resistance bacteria using dielectric barrier discharge and nano-second pulsed plasma. Sci. Rep. 2015, 5, 13849. [CrossRef]

28. Shaw, P.; Kumar, N.; Kwak, H.S.; Park, J.H.; Uhm, H.S.; Bogaerts, A.; Choi, E.H.; Attri, P. Bacterial inactivation by plasma treated water enhanced by reactive nitrogen species. Sci. Rep. 2018, 8, 11268. [CrossRef]

29. Privat-Maldonado, A.; O'Connell, D.; Welch, E.; Vann, R.; Van Der Woude, M.W. Spatial Dependence of DNA Damage in Bacteria due to Lowerature Plasma Application as Assessed at the Single Cell Level. Sci. Rep. 2016, 6, 1-10. [CrossRef]

30. Ji, S.-H.; Kim, J.-S.; Lee, C.-H.; Seo, H.-S.; Chun, S.-C.; Oh, J.; Choi, E.-H.; Park, G. Enhancement of vitality and activity of a plant growth-promoting bacteria (PGPB) by atmospheric pressure nonthermal plasma. Sci. Rep. 2019, 9, 1044. [CrossRef]

31. Waghmare, R. Cold plasma technology for fruit based beverages: A review. Trends Food Sci. Technol. 2021, 114, 60-69. [CrossRef]

32. Sonoda, T.; Takamura, N.; Wang, D.; Namihira, T.; Akiyama, H. Growth control of leaf lettuce using pulsed electric field. In Proceedings of the Digest of Technical Papers-IEEE International Pulsed Power Conference, San Francisco, CA, USA, 16-21 June 2013; pp. 1-5.

33. Eing, C.J.; Bonnet, S.; Pacher, M.; Puchta, H.; Frey, W. Effects of nanosecond pulsed electric field exposure on arabidopsis thaliana IEEE Trans. Dielectr. Electr. Insul. 2009, 16, 1322-1328. [CrossRef]

34. Leong, S.Y.; Burritt, D.J.; Oey, I. Electropriming of wheatgrass seeds using pulsed electric fields enhances antioxidant metabolism and the bioprotective capacity of wheatgrass shoots. Sci. Rep. 2016, 6, 1-13. [CrossRef]

35. Ahmed, Z.; Manzoor, M.F.; Ahmad, N.; Zeng, X.A.; Din, Z.U.; Roobab, U.; Qayum, A.; Siddique, R.; Siddeeg, A.; Rahaman, A Impact of pulsed electric field treatments on the growth parameters of wheat seeds and nutritional properties of their wheat plantlets juice. Food Sci. Nutr. 2020, 8, 2490-2500. [CrossRef]

36. Khotimah, S.N.; Romadhon, D.R.; Viridi, S. The effects of static electric field on germination and growth of mungbean seeds (Vigna radiata L) in vegetative phase. ARPN J. Eng. Appl. Sci. 2016, 11, 13740-13743.

37. Lynikiene, S.; Pozeliene, A. View of Effect of Electrical Field on Barley Seed Germination Stimulation. Available online: https:/ / cigrjournal.org/index.php/Ejounral/article/view/408/403 (accessed on 10 November 2021).

38. Shi, M.F.; Fan, J.J.; Li, S.J.; Yu, X.L.; Liang, X.M. The influence of high voltage electric field for barley seed germination and its mechanism. In Applied Mechanics and Materials; Trans Tech Publications Ltd.: Stafa-Zurich, Switzerland, 2014; Volume 675-677, pp. 1142-1145.

39. Mahajan, T.S.; Pandey, O.P. Effect of electric and magnetic treatments on germination of bitter gourd (Momordica charantia) seed. Int. J. Agric. Biol. 2015, 17, 351-356.

40. Nisar, K.; Sangma, K.; Rani, S. Effect of electric treatment on germination, seedling growth and water uptake in chickpea seed. African J. Agron. 2018, 6, 383-392.

41. Afrasiyab, A.; Zafar, J.; Muhmmad, H. Effect of electric field on seed germination and growth parameters of chickpea Cicer arietinum L. Ukr. J. Ecol. 2020, 10, 12-16. [CrossRef] 
42. Patwardhan, M.S.; Gandhare, W.Z. High voltage electric field effects on the germination rate of tomato seeds. Acta Agrophysica 2013, 20, 403-413.

43. Rezaei-Zarchi, S.; Imani, S.; Alikhani-Mehrjerdi, H.; Reza-Mohebbifar, M. The effect of electric field on the germination and growth of Medicago sativa planet, as a native Iranian alfalfa seed. Acta Agric. Serbica 2012, XVII, 105-115.

44. Srikanth, D. Influence of Magnetic and Electric Field on Germination Attributes of Chilli (Capsicum annum L.) Seeds. Int. J. Pure Appl. Biosci. 2018, 6, 496-501. [CrossRef]

45. Foshee, W.G.; Kirkici, H.; Hung, J.Y.; Blythe, E.K.; Goel, A.; Wehtje, G.R. Seedling emergence of smallflower morningglory and green foxtail subjected to a pulsed electric field. Int. J. Veg. Sci. 2007, 13, 61-72. [CrossRef]

46. Dymek, K.; Dejmek, P.; Panarese, V.; Vicente, A.A.; Wadsö, L.; Finnie, C.; Galindo, F.G. Effect of pulsed electric field on the germination of barley seeds. LWT-Food Sci. Technol. 2012, 47, 161-166. [CrossRef]

47. Li, Y.-Q. Structure Changes of Soybean Protein Isolates by Pulsed Electric Fields. Phys. Procedia 2012, 33, 132-137. [CrossRef]

48. Liu, Y.Y.; Zeng, X.A.; Deng, Z.; Yu, S.J.; Yamasaki, S. Effect of pulsed electric field on the secondary structure and thermal properties of soy protein isolate. Eur. Food Res. Technol. 2011, 233, 841-850. [CrossRef]

49. Li, Y.Q.; Chen, Q.; Liu, X.H.; Chen, Z.X. Inactivation of soybean lipoxygenase in soymilk by pulsed electric fields. Food Chem. 2008, 109, 408-414. [CrossRef] [PubMed]

50. Riener, J.; Noci, F.; Cronin, D.A.; Morgan, D.J.; Lyng, J.G. Combined effect of temperature and pulsed electric fields on soya milk lipoxygenase inactivation. Eur. Food Res. Technol. 2008, 227, 1461-1465. [CrossRef]

51. Zhong, K.; Hu, X.; Zhao, G.; Chen, F.; Liao, X. Inactivation and conformational change of horseradish peroxidase induced by pulsed electric field. Food Chem. 2005, 92, 473-479. [CrossRef]

52. Zhao, W.; Yang, R. The effect of pulsed electric fields on the inactivation and structure of lysozyme. Food Chem. 2008, 110, 334-343. [CrossRef] [PubMed]

53. Perez, O.E.; Pilosof, A.M.R. Pulsed electric fields effects on the molecular structure and gelation of $\beta$-lactoglobulin concentrate and egg white. Food Res. Int. 2004, 37, 102-110. [CrossRef]

54. Yang, W.; Tu, Z.; Wang, H.; Zhang, L.; Gao, Y.; Li, X.; Tian, M. Immunogenic and structural properties of ovalbumin treated by pulsed electric fields. Int. J. Food Prop. 2018, 20, S3164-S3176. [CrossRef]

55. Yang, R.; Li, S.Q.; Zhang, Q.H. Effects of pulsed electric fields on the activity and structure of pepsin. J. Agric. Food Chem. 2004, 52, 7400-7406. [CrossRef] [PubMed]

56. Zhao, W.; Yang, R. Effect of high-intensity pulsed electric fields on the activity, conformation and self-aggregation of pepsin. Food Chem. 2009, 114, 777-781. [CrossRef]

57. Zhang, L.; Wang, L.J.; Jiang, W.; Qian, J.Y. Effect of pulsed electric field on functional and structural properties of canola protein by pretreating seeds to elevate oil yield. LWT-Food Sci. Technol. 2017, 84, 73-81. [CrossRef]

58. Aguiló-Aguayo, I.; Odriozola-Serrano, I.; Quintão-Teixeira, L.J.; Martín-Belloso, O. Inactivation of tomato juice peroxidase by high-intensity pulsed electric fields as affected by process conditions. Food Chem. 2008, 107, 949-955. [CrossRef]

59. Riener, J.; Noci, F.; Cronin, D.A.; Morgan, D.J.; Lyng, J.G. Combined effect of temperature and pulsed electric fields on apple juice peroxidase and polyphenoloxidase inactivation. Food Chem. 2008, 109, 402-407. [CrossRef]

60. Marsellés-Fontanet, Á.R.; Martín-Belloso, O. Optimization and validation of PEF processing conditions to inactivate oxidative enzymes of grape juice. J. Food Eng. 2007, 83, 452-462. [CrossRef]

61. Elez-Martínez, P.; Suárez-Recio, M.; Martín-Belloso, O. Modeling the reduction of pectin methyl esterase activity in orange juice by high intensity pulsed electric fields. J. Food Eng. 2007, 78, 184-193. [CrossRef]

62. Riener, J.; Noci, F.; Cronin, D.A.; Morgan, D.J.; Lyng, J.G. Combined effect of temperature and pulsed electric fields on pectin methyl esterase inactivation in red grapefruit juice (Citrus paradisi). Eur. Food Res. Technol. 2009, 228, 373-379. [CrossRef]

63. Guionet, A.; Fujiwara, T.; Sato, H.; Takahashi, K.; Takaki, K.; Matsui, M.; Tanino, T.; Ohshima, T. Pulsed electric fields act on tryptophan to inactivate $\alpha$-amylase. J. Electrostat. 2021, 112, 103597. [CrossRef]

64. Okumura, T.; Yaegashi, T.; Fujiwara, T.; Takahashi, K.; Takaki, K.; Kudo, T. Influence of pulsed electric field on enzymes, bacteria and volatile flavor compounds of unpasteurized sake. Plasma Sci. Technol. 2018, 20, 044008. [CrossRef]

65. Suriyasak, C.; Hatanaka, K.; Tanaka, H.; Okumura, T.; Yamashita, D.; Attri, P.; Koga, K.; Shiratani, M.; Hamaoka, N.; Ishibashi, Y. Alterations of DNA Methylation Caused by Cold Plasma Treatment Restore Delayed Germination of Heat-Stressed Rice (Oryza Sativa L.) Seeds. ACS Agric. Sci. Technol. 2021, 1, 5-10. [CrossRef]

66. Billah, M.; Karmakar, S.; Mina, F.B.; Haque, M.N.; Rashid, M.M.; Hasan, M.F.; Acharjee, U.K.; Talukder, M.R. Investigation of mechanisms involved in seed germination enhancement, enzymatic activity and seedling growth of rice (Oryza Sativa L.) using LPDBD (Ar+Air) plasma. Arch. Biochem. Biophys. 2021, 698, 108726. [CrossRef]

67. Khamsen, N.; Onwimol, D.; Teerakawanich, N.; Dechanupaprittha, S.; Kanokbannakorn, W.; Hongesombut, K.; Srisonphan, S. Rice (Oryza Sativa L.) Seed Sterilization and Germination Enhancement via Atmospheric Hybrid Nonthermal Discharge Plasma. ACS Appl. Mater. Interfaces 2016, 8, 19268-19275. [CrossRef]

68. Tanakaran, Y.; Matra, K. The Influence of Atmospheric Non-thermal Plasma on Jasmine Rice Seed Enhancements. J. Plant Growth Regul. 2021, 1-10. [CrossRef]

69. Chen, H.H.; Chang, H.C.; Chen, Y.K.; Hung, C.L.; Lin, S.Y.; Chen, Y.S. An improved process for high nutrition of germinated brown rice production: Low-pressure plasma. Food Chem. 2016, 191, 120-127. [CrossRef] [PubMed] 
70. Attri, P.; Ishikawa, K.; Okumura, T.; Koga, K.; Shiratani, M.; Mildaziene, V. Impact of seed color and storage time on the radish seed germination and sprout growth in plasma agriculture. Sci. Rep. 2021, 11, 2539. [CrossRef] [PubMed]

71. Kitazaki, S.; Sarinont, T.; Koga, K.; Hayashi, N.; Shiratani, M. Plasma induced long-term growth enhancement of Raphanus sativus L. using combinatorial atmospheric air dielectric barrier discharge plasmas. Curr. Appl. Phys. 2014, 14, S149-S153. [CrossRef]

72. Sarinont, T.; Amano, T.; Attri, P.; Koga, K.; Hayashi, N.; Shiratani, M. Effects of plasma irradiation using various feeding gases on growth of Raphanus sativus L. Arch. Biochem. Biophys. 2016, 605, 129-140. [CrossRef]

73. Hayashi, N.; Ono, R.; Shiratani, M.; Yonesu, A. Antioxidative activity and growth regulation of Brassicaceae induced by oxygen radical irradiation. Jpn. J. Appl. Phys. 2015, 54, 06GD01. [CrossRef]

74. Matra, K. Non-thermal Plasma for Germination Enhancement of Radish Seeds. Procedia Comput. Sci. 2016, 86, 132-135. [CrossRef]

75. Kitazaki, S.; Koga, K.; Shiratani, M.; Hayashi, N. Growth Enhancement of Radish Sprouts Induced by Low Pressure O\$_\{2\}\$ Radio Frequency Discharge Plasma Irradiation. Jpn. J. Appl. Phys. 2012, 51, 01AE01. [CrossRef]

76. Hayashi, N.; Ono, R.; Uchida, S. Growth Enhancement of Plant by Plasma and UV Light Irradiation to Seeds. J. Photopolym. Sci. Technol. 2015, 28, 445-448. [CrossRef]

77. Li, L.; Chen, J.; Wang, H.; Guo, H.; Li, D.; Li, J.; Liu, J.; Shao, H.; Zong, J. Cold plasma treatment improves seed germination and accelerates the establishment of centipedegrass. Crop Sci. 2021, 61, 2827-2836. [CrossRef]

78. Ahmed, N.; Masood, A.; Siow, K.S.; Wee, M.F.M.R.; Auliya, R.Z.; Ho, W.K. Effect of H2O-Based Low-Pressure Plasma (LPP) Treatment on the Germination of Bambara Groundnut Seeds. Agronomy 2021, 11, 338. [CrossRef]

79. Wannicke, N.; Wagner, R.; Stachowiak, J.; Nishime, T.M.C.; Ehlbeck, J.; Weltmann, K.D.; Brust, H. Efficiency of plasma-processed air for biological decontamination of crop seeds on the premise of unimpaired seed germination. Plasma Process. Polym. 2021, 18, 2000207. [CrossRef]

80. Song, J.-S.; Lee, M.J.; Ra, J.E.; Lee, K.S.; Eom, S.; Ham, H.M.; Kim, H.Y.; Kim, S.B.; Lim, J. Growth and bioactive phytochemicals in barley (Hordeum vulgare L.) sprouts affected by atmospheric pressure plasma during seed germination. J. Phys. D. Appl. Phys. 2020, 53, 314002. [CrossRef]

81. Dubinov, A.E.; Lazarenko, E.M.; Selemir, V.D. Effect of glow discharge air plasma on grain crops seed. IEEE Trans. Plasma Sci. 2000, 28, 180-183. [CrossRef]

82. Švubová, R.; Slováková, L.; Holubová, L.; Rovňanová, D.; Gálová, E.; Tomeková, J. Evaluation of the impact of cold atmospheric pressure plasma on soybean seed germination. Plants 2021, 10, 177. [CrossRef] [PubMed]

83. Pérez-Pizá, M.C.; Cejas, E.; Zilli, C.; Prevosto, L.; Mancinelli, B.; Santa-Cruz, D.; Yannarelli, G.; Balestrasse, K. Enhancement of soybean nodulation by seed treatment with non-thermal plasmas. Sci. Rep. 2020, 10, 4917. [CrossRef]

84. Li, L.; Jiang, J.; Li, J.; Shen, M.; He, X.; Shao, H.; Dong, Y. Effects of cold plasma treatment on seed germination and seedling growth of soybean. Sci. Rep. 2014, 4, 5859. [CrossRef]

85. Šerá, B.; Šerý, M.; Zahoranová, A.; Tomeková, J. Germination Improvement of Three Pine Species (Pinus) After Diffuse Coplanar Surface Barrier Discharge Plasma Treatment. Plasma Chem. Plasma Process. 2021, 41, 211-226. [CrossRef]

86. Karmakar, S.; Billah, M.; Hasan, M.; Sohan, S.R.; Hossain, M.F.; Faisal Hoque, K.M.; Kabir, A.H.; Rashid, M.M.; Talukder, M.R.; Reza, M.A. Impact of LFGD $\left(\mathrm{Ar}+\mathrm{O}_{2}\right)$ plasma on seed surface, germination, plant growth, productivity and nutritional composition of maize (Zea mays L.). Heliyon 2021, 7, e06458. [CrossRef]

87. Henselová, M.; Slováková, L'.; Martinka, M.; Zahoranová, A. Growth, anatomy and enzyme activity changes in maize roots induced by treatment of seeds with low-temperature plasma. Biologia 2012, 67, 490-497. [CrossRef]

88. Iqbal, T.; Farooq, M.; Afsheen, S.; Abrar, M.; Yousaf, M.; Ijaz, M. Cold plasma treatment and laser irradiation of Triticum spp seeds for sterilization and germination. J. Laser Appl. 2019, 31, 042013. [CrossRef]

89. Jiang, J.; He, X.; Li, L.; Li, J.; Shao, H.; Xu, Q.; Ye, R.; Dong, Y. Effect of Cold Plasma Treatment on Seed Germination and Growth of Wheat. Plasma Sci. Technol. 2014, 16, 54-58. [CrossRef]

90. Dobrin, D.; Magureanu, M.; Mandache, N.B.; Ionita, M.-D. The effect of nonthermal plasma treatment on wheat germination and early growth. Innov. Food Sci. Emerg. Technol. 2015, 29, 255-260. [CrossRef]

91. Sohan, M.S.R.; Hasan, M.; Hossain, M.F.; Sajib, S.A.; Miah, M.M.; Iqbal, M.A.; Karmakar, S.; Alam, M.J.; Khalid-Bin-Ferdaus, K.M.; Kabir, A.H.; et al. Improvement of Seed Germination Rate, Agronomic Traits, Enzymatic Activity and Nutritional Composition of Bread Wheat (Triticum aestivum) Using Low-Frequency Glow Discharge Plasma. Plasma Chem. Plasma Process. 2021, 41, 923-944. [CrossRef]

92. Molina, R.; Lalueza, A.; López-Santos, C.; Ghobeira, R.; Cools, P.; Morent, R.; de Geyter, N.; González-Elipe, A.R. Physicochemical surface analysis and germination at different irrigation conditions of DBD plasma-treated wheat seeds. Plasma Process. Polym. 2021, 18, e2000086. [CrossRef]

93. Roy, N.C.; Hasan, M.M.; Talukder, M.R.; Hossain, M.D.; Chowdhury, A.N. Prospective Applications of Low Frequency Glow Discharge Plasmas on Enhanced Germination, Growth and Yield of Wheat. Plasma Chem. Plasma Process. 2018, 38, 13-28. [CrossRef]

94. Šerá, B.; Špatenka, P.; Šerý, M.; Vrchotová, N.; Hrušková, I. Influence of plasma treatment on wheat and oat germination and early growth. IEEE Trans. Plasma Sci. 2010, 38, 2963-2968. [CrossRef]

95. Meng, Y.; Qu, G.; Wang, T.; Sun, Q.; Liang, D.; Hu, S. Enhancement of Germination and Seedling Growth of Wheat Seed Using Dielectric Barrier Discharge Plasma with Various Gas Sources. Plasma Chem. Plasma Process. 2017, 37, 1105-1119. [CrossRef] 
96. Li, Y.; Wang, T.; Meng, Y.; Qu, G.; Sun, Q.; Liang, D.; Hu, S. Air Atmospheric Dielectric Barrier Discharge Plasma Induced Germination and Growth Enhancement of Wheat Seed. Plasma Chem. Plasma Process. 2017, 37, 1621-1634. [CrossRef]

97. Guo, Q.; Wang, Y.; Zhang, H.; Qu, G.; Wang, T.; Sun, Q.; Liang, D. Alleviation of adverse effects of drought stress on wheat seed germination using atmospheric dielectric barrier discharge plasma treatment. Sci. Rep. 2017, 7, 16680. [CrossRef]

98. Lotfy, K.; Al-Harbi, N.A.; Abd El-Raheem, H. Cold Atmospheric Pressure Nitrogen Plasma Jet for Enhancement Germination of Wheat Seeds. Plasma Chem. Plasma Process. 2019, 39, 897-912. [CrossRef]

99. Nishime, T.M.C.; Wannicke, N.; Horn, S.; Weltmann, K.D.; Brust, H. A coaxial dielectric barrier discharge reactor for treatment of winter wheat seeds. Appl. Sci. 2020, 10, 7133. [CrossRef]

100. Saberi, M.; Modarres-Sanavy, S.A.M.; Zare, R.; Ghomi, H. Improvement of photosynthesis and photosynthetic productivity of winter wheat by cold plasma treatment under haze condition. J. Agric. Sci. Technol. 2020, 21, 1889-1904.

101. Stolárik, T.; Henselová, M.; Martinka, M.; Novák, O.; Zahoranová, A.; Černák, M. Effect of Low-Temperature Plasma on the Structure of Seeds, Growth and Metabolism of Endogenous Phytohormones in Pea (Pisum sativum L.). Plasma Chem. Plasma Process. 2015, 35, 659-676. [CrossRef]

102. Khatami, S.; Ahmadinia, A. Increased germination and growth rates of pea and Zucchini seed by FSG plasma. J. Theor. Appl. Phys. 2018, 12, 33-38. [CrossRef]

103. Tomeková, J.; Kyzek, S.; Medvecká, V.; Gálová, E.; Zahoranová, A. Influence of Cold Atmospheric Pressure Plasma on Pea Seeds: DNA Damage of Seedlings and Optical Diagnostics of Plasma. Plasma Chem. Plasma Process. 2020, 40, 1571-1584. [CrossRef]

104. Zhou, R.; Zhou, R.; Zhang, X.; Zhuang, J.; Yang, S.; Bazaka, K.; Ostrikov, K.K. Effects of Atmospheric-Pressure N2, He, Air, and $\mathrm{O}_{2}$ Microplasmas on Mung Bean Seed Germination and Seedling Growth. Sci. Rep. 2016, 6, 32603. [CrossRef]

105. Gholami, A.; Safa, N.N.; Khoram, M.; Hadian, J.; Ghomi, H. Effect of Low-Pressure Radio Frequency Plasma on Ajwain Seed Germination. Plasma Med. 2016, 6, 389-396. [CrossRef]

106. Šerá, B.; Gajdová, I.; Šerý, M.; Špatenka, P. New Physicochemical Treatment Method of Poppy Seeds for Agriculture and Food Industries. Plasma Sci. Technol. 2013, 15, 935-938. [CrossRef]

107. Ling, L.; Jiangang, L.; Minchong, S.; Chunlei, Z.; Yuanhua, D. Cold plasma treatment enhances oilseed rape seed germination under drought stress. Sci. Rep. 2015, 5, 13033. [CrossRef] [PubMed]

108. Singh, R.; Prasad, P.; Mohan, R.; Verma, M.K.; Kumar, B. Radiofrequency cold plasma treatment enhances seed germination and seedling growth in variety CIM-Saumya of sweet basil (Ocimum basilicum L.). J. Appl. Res. Med. Aromat. Plants 2019, $12,78-81$. [CrossRef]

109. Billah, M.; Sajib, S.A.; Roy, N.C.; Rashid, M.M.; Reza, M.A.; Hasan, M.M.; Talukder, M.R. Effects of DBD air plasma treatment on the enhancement of black gram (Vigna mungo L.) seed germination and growth. Arch. Biochem. Biophys. 2020, 681, 108253. [CrossRef] [PubMed]

110. Wojtyla, Ł.; Lechowska, K.; Kubala, S.; Garnczarska, M. Different modes of hydrogen peroxide action during seed germination. Front. Plant Sci. 2016, 7, 66. [CrossRef] [PubMed]

111. Barba-Espin, G.; Diaz-Vivancos, P.; Clemente-Moreno, M.J.; Albacete, A.; Faize, L.; Faize, M.; Pérez-Alfocea, F.; Hernández, J.A. Interaction between hydrogen peroxide and plant hormones during germination and the early growth of pea seedlings. Plant. Cell Environ. 2010, 33, 981-994. [CrossRef]

112. Li, H.P.; Wang, L.Y.; Li, G.; Jin, L.H.; Le, P.S.; Zhao, H.X.; Xing, X.H.; Bao, C.Y. Manipulation of lipase activity by the helium radio-frequency, atmospheric-pressure glow discharge plasma jet. Plasma Process. Polym. 2011, 8, 224-229. [CrossRef]

113. Takai, E.; Kitano, K.; Kuwabara, J.; Shiraki, K. Protein inactivation by low-temperature atmospheric pressure plasma in aqueous solution. Plasma Process. Polym. 2012, 9, 77-82. [CrossRef]

114. Choi, S.; Attri, P.; Lee, I.; Oh, J.; Yun, J.-H.; Park, J.H.; Choi, E.H.; Lee, W. Structural and functional analysis of lysozyme after treatment with dielectric barrier discharge plasma and atmospheric pressure plasma jet. Sci. Rep. 2017, 7, 1027. [CrossRef]

115. Attri, P.; Venkatesu, P.; Kaushik, N.; Han, Y.G.; Nam, C.J.; Choi, E.H.; Kim, K.S. Effects of atmospheric-pressure nonthermal plasma jets on enzyme solutions. J. Korean Phys. Soc. 2012, 60, 959-964. [CrossRef]

116. Attri, P.; Kumar, N.; Park, J.H.; Yadav, D.K.; Choi, S.; Uhm, H.S.; Kim, I.T.; Choi, E.H.; Lee, W. Influence of reactive species on the modification of biomolecules generated from the soft plasma. Sci. Rep. 2015, 5, 8221. [CrossRef]

117. Attri, P.; Sarinont, T.; Kim, M.; Amano, T.; Koga, K.; Cho, A.E.; Choi, E.H.; Shiratani, M. Influence of ionic liquid and ionic salt on protein against the reactive species generated using dielectric barrier discharge plasma. Sci. Rep. 2015, 5, 17781. [CrossRef] [PubMed]

118. Park, J.H.; Kim, M.; Shiratani, M.; Cho, A.E.; Choi, E.H.; Attri, P. Variation in structure of proteins by adjusting reactive oxygen and nitrogen species generated from dielectric barrier discharge jet. Sci. Rep. 2016, 6, 35883. [CrossRef] [PubMed]

119. Segat, A.; Misra, N.N.; Cullen, P.J.; Innocente, N. Effect of atmospheric pressure cold plasma (ACP) on activity and structure of alkaline phosphatase. Food Bioprod. Process. 2016, 98, 181-188. [CrossRef]

120. Attri, P.; Han, J.; Choi, S.; Choi, E.H.; Bogaerts, A.; Lee, W. CAP modifies the structure of a model protein from thermophilic bacteria: Mechanisms of CAP-mediated inactivation. Sci. Rep. 2018, 8, 10218. [CrossRef]

121. Zhang, H.; Ma, J.; Shen, J.; Lan, Y.; Ding, L.; Qian, S.; Cheng, C.; Xia, W.; Chu, P.K. Comparison of the Effects Induced by Plasma Generated Reactive Species and $\mathrm{H}_{2} \mathrm{O}_{2}$ on Lactate Dehydrogenase (LDH) Enzyme. IEEE Trans. Plasma Sci. 2018, 46, 2742-2752. [CrossRef] 
122. Attri, P.; Park, J.H.; De Backer, J.; Kim, M.; Yun, J.H.; Heo, Y.; Dewilde, S.; Shiratani, M.; Choi, E.H.; Lee, W.; et al. Structural modification of NADPH oxidase activator (Noxa 1) by oxidative stress: An experimental and computational study. Int. J. Biol. Macromol. 2020, 163, 2405-2414. [CrossRef]

123. Lapenna, A.; Fanelli, F.; Fracassi, F.; Armenise, V.; Angarano, V.; Palazzo, G.; Mallardi, A. Direct exposure of dry enzymes to atmospheric pressure non-equilibrium plasmas: The case of tyrosinase. Materials 2020, 13, 2181. [CrossRef]

124. Surowsky, B.; Fischer, A.; Schlueter, O.; Knorr, D. Cold plasma effects on enzyme activity in a model food system. Innov. Food Sci. Emerg. Technol. 2013, 19, 146-152. [CrossRef]

125. Han, Y.X.; Cheng, J.H.; Sun, D.W. Changes in activity, structure and morphology of horseradish peroxidase induced by cold plasma. Food Chem. 2019, 301, 125240. [CrossRef]

126. Khani, M.R.; Shokri, B.; Khajeh, K. Studying the performance of dielectric barrier discharge and gliding arc plasma reactors in tomato peroxidase inactivation. J. Food Eng. 2017, 197, 107-112. [CrossRef]

127. Umair, M.; Jabbar, S.; Nasiru, M.M.; Sultana, T.; Senan, A.M.; Awad, F.N.; Hong, Z.; Zhang, J. Exploring the potential of high-voltage electric field cold plasma (HVCP) using a dielectric barrier discharge (DBD) as a plasma source on the quality parameters of carrot juice. Antibiotics 2019, 8, 235. [CrossRef] [PubMed]

128. Lee, K.H.; Kim, H.J.; Woo, K.S.; Jo, C.; Kim, J.K.; Kim, S.H.; Park, H.Y.; Oh, S.K.; Kim, W.H. Evaluation of cold plasma treatments for improved microbial and physicochemical qualities of brown rice. LWT-Food Sci. Technol. 2016, 73, 442-447. [CrossRef] 